\title{
The GAS/BITUMEN DISPUTE: The Clash of Fact, Technology, Policy and LaW
}

\author{
ALlan L. MCLARTY" AND GEORGE V. LEPINE"•
}

This article examines the conflict benveen gas production and the preservation of bisumen resources in Alberla's oil sands area. Afler providing a synopsis of the relevant tectinical and legal issues facing the industry, the authors then focus on the clash of factual, technological. legal and policy issues facing both regulators and industry in the gas/bitumen dispute. The authors then conclude with an analysis of the current status and future of the gas/bitumen dispute.
Cet arricle porte sur le conflit entre la production de gaz naturel et la conservation des réserves de bitume dans la région des sables bitumineux en Alberla. Après avoir donné im sommaire dex questions rechniques et juridigues pertinentes anuquelles l'industrie doit faire face. les auteurs se concentrent sur le conflir des questions factuelles, rechnologiques, juridiques et de politique avec lesquelles les organismes de réglementation etl'industrie du bitume et gaz naturel doivent composer. Les auteurs terminent par une analyse de la situation actuelle et future dit confit existant aurour dit bitume et gas naturel.

\section{TABLE OF CONTENTS}

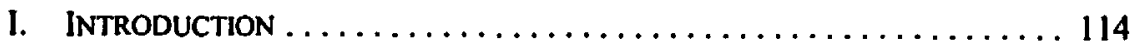

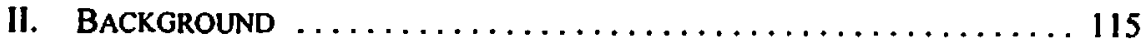

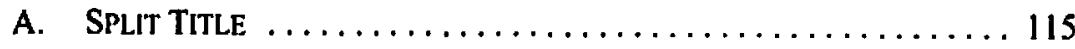

B. Steam Assisted Gravity Drainage $\ldots \ldots \ldots \ldots \ldots \ldots \ldots 117$

C. The Gas/Bitumen InQuiry $\ldots \ldots \ldots \ldots \ldots \ldots \ldots \ldots \ldots \ldots \ldots \ldots \ldots \ldots \ldots$

D. INTERIM DiRECTIVE $99-1 \ldots \ldots \ldots \ldots \ldots \ldots \ldots \ldots \ldots \ldots \ldots$

E. GULF CANADA RESOURCES LIMITED, REQUEST FOR THE SHUT-IN OF ASSOCIATED GAS, SURMONT AREA ............ 119

F. CHARD AREA AND LEISMER FIELD, ATHABASCA OLL SANDS AREA, APPLICATIONS FOR THE PRODUCTION AND SHUT-IN OF GAS ..... 120

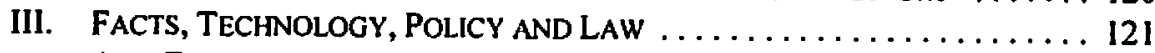

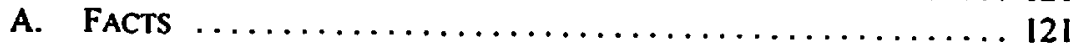

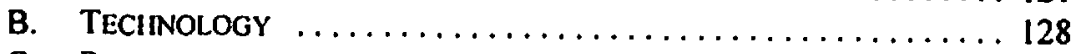

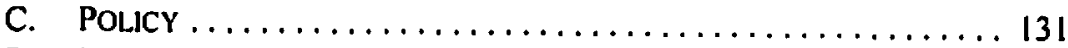

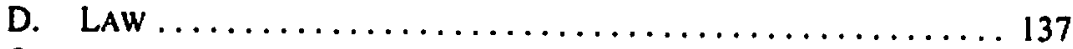

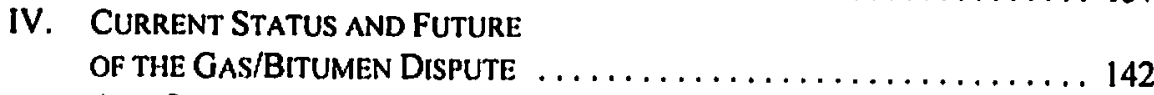

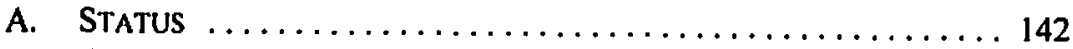

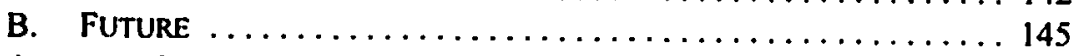

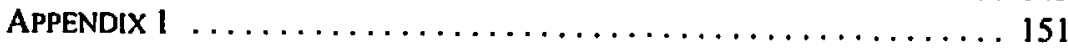

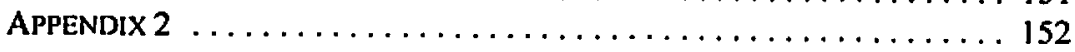

Senior partner, Energy Law Group, Fraser Milner Casgrain LLP, Calgary, Alberta. Independent energy lawyer who formerly managed BP Canada Energy Corporation's participation in the Alberta Energy and Utilities Board Chard-Leismer proceeding, infra note 4. 


\section{INTRODUCTION}

The gas over bitumen issue involves a conflict between the development of what are arguably Alberta's two most important natural resources: natural gas and bitumen.' The issue has arisen over concerns that reservoir pressure depletion caused by gas production may be detrimental to production of underlying bitumen deposits in parts of northeast Alberta.

The gas over bitumen issue is big and is continuing to grow. It is an issue for the province of Alberta, the Alberta public interest and the Alberta energy industry. To put what is at stake in perspective, the Alberta Energy and Utilities Board (AEUB) indicated that the bitumen resource on the Surmont leases alone is greater than all of the light-medium crude oil produced in Alberta as of year-end 1998. ${ }^{2}$ It is the magnitude of the potential impact to the bitumen resource that has led the AEUB to conclude that the gas/bitumen issue is of sufficient significance to warrant considering protection by precluding or shutting in gas production.

This type of protection does not come without a cost. A tri-party compensation agreement reached between the Alberta Department of Energy, Conoco-Phillips Canada (formerly Gulf Canada Resources Limited) and the Surmont Gas Producers' in 2002 resulted in the provision of an $\$ 85,000,000$ compensation package to the Surmont Gas Producers.

This appears to be but the tip of the iceberg. More recently, the AEUB found that "the existence of a significant amount of potentially recoverable bitumen in the Chard-Leismer area ... warrants consideration for protection for future development." The AEUB determined that protection was appropriate to the extent that it denied approval to produce in respect of 21 wells perforated within the Wabiskaw-McMurray formation and ordered the shut-in of 39 wells producing from specific perforated intervals in the Wabiskaw-McMurray formation. The AEUB identified another 139 producing wells within the Chard-Leismer area that it concluded could present a significant risk to future bitumen recovery. The AEUB further expressed the belief that other producing wells in other areas of the Athabasca Wabiskaw-McMurray deposit may also present a significant risk to future bitumen recovery. ${ }^{3}$

Further enlarging the potential impact, the AEUB issued a General Bulletin ${ }^{6}$ to all oil, gas and oil sands operators, inviting submissions on whether existing gas production from the Wabiskaw-McMurray formation in the Athabasca Oil Sands Area should be shut-in, and/or

Bitumen or crude bitumen refers to the tar-like hydrocarbon substance contained in oil sands.

Gulf Canada Resources Limired, Request for the Shut-In of Associated Gas, Surmont Area, (March 2001), AEUB Decision 2000-22 (AEUB), online: AEUB <wiw.cub.gov.ab.ca/BBS/documenls/ decisions $/ 2000 / 2000-22$.pdis [2000-22].

3 Canadian Forest Oil \& Gas L.ld., Giant Grosmont Petroleums Ltd., NAL Resources Ltd., Northstar Energy Corporation, Ocean Energy Resources Canada L.t.. Paramount Resources L.td and Rio Alto Exploration L.ld.

+ (Whard Area and Leismer Field. Athabasca Oil Sands Area, Applications for the Production and ShurII of Gas (18 March 2003) ALUB Decision 2003-023 (ALUB) at II, online: AEUB <www.euh.gov. ab.ca/ BBS/documents/decisions/2003/2003-023.pdP [2003-023].

lbid. at vii.

(3 April 2003), AEUB General Bulletin 2003-12 (AEUB), online: <www.eub.gov.ab.ca/BBS/ requirements/ils/gbs/gb2003-12.htm> [GB 2003-12]. 
whether any alternative measures might be taken to ensure the conservation of bitumen. $G B$ 2003-12 includes the ominous indication that the AEUB "intends to take such steps as it believes necessary to effect the conservation of bitumen in the Wabiskaw-McMurray Formation."

The scope of the issue has been expanded to encompass a large number of the wells in the Athabasca Oil Sands Deposit. A map reproduced from the AEUB's Interim Directive ID 991 , which shows the magnitude of the impact area, is attached as Appendix $1 .^{8}$

The gas/bitumen issue is obviously far from being resolved and the significance of the issue continues to expand. This absence of resolution might seem a little surprising, given that the issue has already given rise to three major AEUB proceedings, resulting in the Gas/Bitumen in Oil Sands Areas Inquiry Report,' the 2000-22 decision ${ }^{10}$ and the 2003-023 decision." Those three proceedings have resulted in 132 AEUB hearing sitting days (excluding pre-hearing meetings and interim applications). During those proceedings more than 1,300 exhibits have been filed, which have been spoken to by some 138 individual witnesses. Evidence, when expanded by cross-examination and argument, ${ }^{12}$ has resulted in more than 22,000 pages of transcripts.

What then is this issue all about and what is its likely future? There are relatively few facts that are settled and the science contributed in respect of technological issues could easily support a few Ph.D. theses. Policy positions advanced have covered the political and fairness spectrum and the issue has been a hot bed for new law and regulatory practice. This article is designed to canvass some of the more significant of these points and to ask and answer where the issue is now and what should be expected in the future.

\section{BACKground}

\section{A. Split Title}

The gas/bitumen dispute had its origins primarily in fact and in law. Factually, both the gas pools and oil sands resources that are at issue exist within the Wabiskaw-McMurray deposit. Historically, gas and bitumen within a common zone were treated by the Alberta Department of Energy and its departmental predecessors, for lease tenure purposes, as a single resource. For regulatory purposes, the gas within the oil sands zones was considered generally in the manner of a gas cap of a conventional oil pool. This treatment resulted in lease tenure provisions being clarified in 1957 so as to clearly except bituminous sands from

Ibid. at 2.

(3 February 1999). AEUB Interim Directive ID 99-I (as amended) online: AEUB <www.cub.gov. ab.ca/bbs/ils/ids/pdffid99-01.pdis at 22 [ID 99-1].

" (I March 1998), AEUB Inquiry (AEUB), online: AEUB <www.eub.gov.ab.ca/BBS/documents/ decisions/1998/GasBitumen 1998.pdi> [Inquiry Report].

11 2000-22, supra note 2.

11 2003-023, supra note 4

12 The argument and reply argument in the 2003-023 proceeding, ibid, was filed in written form totaling more than 1,300 pages. 
every Crown petroleum lease and, simultaneously, bituminous sands were explicitly defined as including all other mineral substances in association therewith. ${ }^{13}$

By the late 1970s the then-current wisdom was that, unlike a conventional oil pool, natural gas pressure support within an oil sands zone was not required for the production of the tarlike bitumen. By legislative amendment "oil sands" was redefined so as to not include petroleum and natural gas that in its naturally-occurring state was recoverable through a well. ${ }^{14}$ This amendment allowed the leasing and production of petroleum and natural gas from an oil sands zone. The Department of Mines and Minerals, by Information Letter 79$14,{ }^{15}$ advised that after 31 December 1981 , undisposed petroleum and natural gas rights in all zones would be offered as leases or licenses. With this, the government, with the strong encouragement of the gas-producing industry, had made the conscious decision that it was in the best interest of the province to make the petroleum and natural gas within existing oil sands deposits a separately available and producible resource. This led to the derivation and characterization of the "split title."

The regulatory regime has, over the years, attempted to parallel the lease tenure regime. The Oil and Gas Conservation Act, until 1983, included the requirement that:

26(1) No scheme for ...

(e) the concurrent production of an oil accumulation and its associated gas cap, or

(f) the production of gas occurring within or immediately adjoining oil sands, ...

shall be proceeded with unless the Board, by order, has approved the sclieme on any lerms and conditions the Board prescribes. $^{16}$

Section 29(1) and (2) of the Oil and Gas Conservation Act coincidentally precluded wells without a scheme approval from producing either from the gas cap of an oil pool or from gas occurring within or immediately adjoining the oil sands.

With the introduction of the Oil Sands Conservation $\mathrm{ACl}^{17}$ in 1983, on the recommendation of the AEUB, the Oil and Gas Conservation ACt was amended and the prohibition against gas production from oil sands areas was repealed, ${ }^{18}$ eliminating the need for scheme approval for the production of gas either within or adjoining oil sands. Thus, tenure and regulatory practice were again brought into alignment.

An ACt to Amend The Mines and Minerals ACl, S.A. 1957, c. 51. which provided with respect to a petroleum and natural gas lease:

23(2) Notwithstanding subsection (1) the lease does not grant the right to bituminous sands or to the petroleum or natural gas that may be recovered therefrom.

14 The Mimes and Minerals Amendment Act, S.A. 1978, c. 23, s. 2.

1" Alberta Energy, Disposition of Petroleum and Natural Gas Rights in Oil Sands Areas - Options Available to Holders of Oil Sands Agreements, online: Alberta Energy <www.energy.gov.ab.ca/com/ Sands/Info+Letters/Information + Letters+-+Oil+Sands+Subject+Index.htm \#1979>.

th R.S.A. 2000 , c. 0.6, s. 26

1" S.A. 1983, c. 0-5.5.

in Supra note 16, s. 30(6) 


\section{B. Steam Assisted Gravity Drainage}

By the late 1980s and early 1990s, a new technology for producing bitumen in situ ${ }^{19}$ was evolving in the form of Steam Assisted Gravity Drainage (SAGD). As described by the AEUB:

In the SAGD process, the oil sands zone is accessed by drilling horizontal well pairs from the surface. The horizontal well pairs are spaced several metres apart vertically as shown in the schematic cross-section of the process in Figure 1.

Upon commencement of the SAGD process, steam is injected into both the upper and lower wells. Once pressure communication has been established between the two wells, steam is injected into the upper well only and the lower well becomes the producer.

During SAGD production, stcam injected into the upper well flows through the bitumen-depleted zone to the cold interface, where it condenses, heating the bitumen. Mobilized bitumen then drains by gravity to the lower well and is produced. As the pay zone is exploited, the steam chamber continues to rise and spread, eventually reaching the top of the bitumen-bearing zone.

This stage of steam chamber development is considered to be the time during which steam breakthrough to an overlying gas cap is most likely to occur.

For those SAGD projects currently under development, several well pairs are arranged with 70 to 90 metres between adjacent welt pairs. Using this configuration, neighbouring steam chambers eventually merge as tlie pay zone is depleted. ${ }^{20}$

SAGD technology was tested in a number of pilot projects such that by the late 1990 s it was considered to be a commercially viable technology for the in situ recovery of bitumen.

\section{The GAS/BITUMEN INQUIRY}

In late 1996, several companies, including Gulf Canada Resources Ltd. (Gulf), represented concerns to the AEUB as to potential adverse effects on the recovery of bitumen if associated gas was produced in advance of the bitumen. ${ }^{21}$ For this reason it was argued that all current and future associated gas production from affected oil sands deposits should be curtailed. ${ }^{22}$ The concern expressed was that the pressure depletion caused by the production of the gas could compromise the recovery efficiency of the SAGD process to such an extent that some SAGD bitumen projects might not be viable. ${ }^{23}$ The AEUB conducted a general inquiry on this issue to solicit the views of all segments of the energy industry.

In sim bitumen is bitumen that is too deep 10 be mined and must therefore be produced using techmeques which separate bitumen from sand in the reservoir.

Inquiry Report, supra note 9 at 2,4 (Figure $I$ is attached as $\Lambda$ ppendix 2). Sec: online: AE:JB - www eub.gov.ab.ca/bbs/documenis/decisions/1998/GasBitumen/998.pdf $\$$ at 3.

Jbid. at v.

lbid.

lbid. 
In its report the AEUB noted that there was little or no actual data concerning the effect of associated gas production on SAGD performance, but concluded that modelling data represented the best available evidence and that "in some instances the effect on the ultimate bitumen recovery could be significant." 24 The AEUB considered arguments as to the existence of various offsetting and potential mitigation measures, but concluded that reliance should not be placed on unproven measures because it would not be in the public interest to risk significant volumes of bitumen resources. ${ }^{25}$

From this the AEUB concluded that some regulatory involvement was warranted and established a policy for the regulation of gas associated with bitumen in oil sands deposits as defined by the AEUB. The AEUB determined "that a concurrent production framework similar to that currently in place for conventional oil should be adopted for bitumen." ${ }^{26}$ The policy established by the AEUB was generally to allow continued gas production from wells completed in oil sands zones prior to 1 July 1998 ("grandfathered wells") and to require licensees to apply for and obtain production approval for wells drilled and completed after 1 July 1998. The AEUB recognized that this policy of allowing production from grandfathered wells might have an impact on future bitumen recovery and, accordingly, reserved the right to consider complaints from oil sands leaseholders or to undertake a review of particular grandfathered wells on its own initiative. ${ }^{27}$ To effect this policy the AEUB issued ID 99.1 in February 1999. ${ }^{23}$

\section{INTERIM DIRECTIVE 99-1}

ID 99-1 outlines the AEUB's criteria for approval of gas production in oil sands areas. The requirements are that:

An application for approval to produce gas from the oil sands strata shall show:

that the gas is not associated with bitumen within the region of influence; ${ }^{29}$ or

if the gas is associated with bitumen within the region of influence, why gas production should be allowed considering the potential effect on future bitumen recovery. ${ }^{30}$

ID 99-1 confirmed the policy approach that "grandfathered wells" will be allowed to continue production, subject to the resolution of any concerns that may be raised by oil sands leaseholders or by the AEUB on its own initiative. The substantive application requirements of ID 99-I were subsequently included in amendments to the Oil and Gas Conservation Acr" and the Oil Sands Conservation Act, ${ }^{32}$ both of which were effective 1 March 1999. The establishment of these regulations corresponded closely with the commencement of the

Ibid. at 48.

lbid. al 48.

lbid. at 51 .

lbid. at 53 .

Supra note 8.

The AEUB's definition of region of influence is "the extent of the gas pool in the case of gas directly overlying bitumen or the combined extent of the gas pool and water zone in the case of gas overlying water overlying bitumen" (ID 99-1, supra note 8 at 2).

Ibid.

Alta. Reg. $47 / 99$.

Alta. Reg. 48/99. 
hearing concerning Gulf's application for the shut-in of gas wells on its Surmont bitumen leases.

\section{E. GULF CANADA RESOURCES LIMITED, REQUEST FOR THE SHUT-IN OF ASSOCIATED GAS, SURMONT AREA}

By mid-1998, Gulf had amended its original complaint to request of the AEUB that:
gas production from the Wabiskaw-McMurray on its Surmont oil sands leases and surrounding three- section buffer area ... be shut in until oil sands development is completed ... and
any further drilling for gas production from the Wabiskaw-McMurray on its Surmont oil sands leases and surrounding area be prohibited until oil sands development is completed. ${ }^{33}$

In its decision on the Gulf application, the AEUB concluded that it "believes that all the Wabiskaw-McMurray gas being produced by wells on the Gulf Surmont leases is or has the potential to be associated with the underlying bitumen, either through direct vertical continuity or indirectly through lateral continuity of the gas and water zones." ${ }^{34}$ Accordingly. the AEUB ordered the shut-in of Wabiskaw-McMurray gas production from 146 of the 183 zones specifically in wells that Gulfhad requested to be shut-in. The AEUB noted that fifteen of the wells that Gulf had requested to be shut-in were not completed in the WabiskawMcMurray zone, according to the AEUB's records. The AEUB expressed a concern with respect to the remaining wells, but noted that they were not a likely risk to bitumen on the Surmont leases.

In its decision, the AEUB again acknowledged that there was limited applicable field experience and confirmed two views it had expressed in the Inquiry Report. First, reservoir modelling reasonably demonstrated that producing associated gas in the Surmont area would likely have a detrimental effect on SAGD bitumen recovery and second, the magnitude of the detrimental effect could be significant. ${ }^{35}$ The AEUB concluded it would not be prudent to wait for more definitive data because waiting would involve a significant risk to future bitumen recovery. ${ }^{36}$ The AEUB repeated an earlier view that offsetting and potential mitigation measures were not sufficiently certain in terms of their effect and should, therefore, not be relied upon. The AEUB further rationalized its conclusion on the basis that "the potential value of the bitumen resources significantly exceeds the value of the remaining gas reserves in the Surmont area and [the AEUB] believes that it would not be in the public interest to accept the possibility of sterilizing a vast bitumen resource by allowing continued gas production."37

\footnotetext{
Supra note 2 at 3.

lbid. at v.

/bid. at vi.

lbid.

hide at vii.
} 


\section{F. CHARD AREA AND LEISMER FIELD, ATHABASCA OIL SANDS AREA, APPLICATIONS FOR THE PRODUCTION AND SHUT-IN OF GAS}

The Chard and Leismer areas are within the Athabasca oil sands deposit, just south and west of the Surmont area. The AEUB concluded that the bitumen resources "in the ChardLeismer area are on trend with Alberta's most significant bitumen deposits, and [the AEUB] notes that most announced and approved commercial stream-assisted gravity drainage (SAGD) projects fall within this trend." ${ }^{\text {33 }}$ The 2003-023 proceeding conducted by the AEUB considered:

- applications by five different gas producers for approval to produce gas from a total of 43 wells that had been completed after 1 July 1998;

- applications from three different bitumen owners that requested the shut-in of a total of 100 grandfathered wells; ${ }^{39}$ and

- a request, in an independent submission from an AEUB Staff Group, for various directives to deal with grandfathered well production both within the Leismer-Chard areas and in other oil sands areas. ${ }^{40}$

In its decision, the AEUB addressed substantially the same scientific and technical issues that had been raised in the earlier Inquiry and 2000-22 proceedings. Much of the evidence and debate centred on the issue of whether the gas could be considered associated with the bitumen and, if so, whether the production of the gas was likely to have any material impact on future bitumen recovery.

The AEUB confirmed the continued limited existence of actual field evidence and indicated that it intended to continue to rely on reservoir modelling to evaluate the issue. Although the AEUB acknowledged the limitations of the models, paying particular regard to the complex reservoir description required for modelling and the possibility that models may not reflect actual field operating parameters, the AEUB nevertheless concluded "that producing gas that is associated with bitumen ... presents an unacceptable risk to SAGD bitumen recovery." ${ }^{\text {"4l }}$ This, the AEUB indicated, is because it

\footnotetext{
bulieves that it should consider the longer-lerm aspects of resource development and the longer-term interests of future Albertans. Therefore, given the number of unknowns about the technical and cconomic parameters surrounding SAGD bitumen recoven; the [AEUB] believes that it has a responsibility to ensure that long-term bitumen recovery is not jeopardized by the production of gas that is in pressure communication with signilicam bitumen resources. ${ }^{42}$
}

In terms of process, the AEUB concluded that the process set out in ID 99-1 continued to be appropriate to ensure that potentially at-risk bitumen is not jeopardized, but it also

The application by PanCanadian Pctruleum L.imited (PanCanadian) for the shut-in of gas wells in and proximate to its Christina Lake SAGD project was withdrawn after the merger of PanCanadian and Alberta Energy Company into EnCana and prior to the conclusion of the 2003-023 hearing.

4. Supra note 4

$1 \quad$ ibid. at 33.

: $\quad$ lbid. at 36 
concluded that there was a need to address further grandfathered gas production in the Athabasca Wabiskaw-McMurray deposit, including that from the Chard-Leismer area.

\section{Facts, Technology, Policy and Law}

As the gas bitumen debate appears only to be warming up, the question that arises is whether the better potential for finding a resolution lies in establishing more and better factual evidence in technology, new policy or law.

\section{A. FACTS}

There are few absolute truths or facts that have served as touchstones in the gas/bitumen debate. In fact, a wide divergence of opinion has been presented with such matters as:

- the size and quality of the bitumen resource to be protected;

- the nature of the Wabiskaw/McMurray geology;

- the potential for pressure communication between gas pools and underlying bitumen;

- the use of pressure monitoring data; and

- the impact that production of associated gas is expected to have on bitumen recoveries.

\section{SIZE AND QUALITY OF ALBERTA'S BITUMEN RESOURCE}

The AEUB's vigilance over protection of bitumen deposits in the Chard-Leismer/Surmont area arises out of the AEUB's belief in what may be among the best in situ deposits in Alberta and out of the importance of the bitumen resource that may be at risk.

As alluded to in the introduction to this article, the AEUB in its 2000-22 decision noted that the bitumen resource on the Surmont leases alone was $2.38510^{9} \mathrm{~m}^{3},{ }^{43}$ which is greater than the total amount of the light-medium crude oil produced in Alberta up to the end of 1998. More significant is that the Surmont bitumen resource represents less than 1 percent of the total bitumen resource in Alberta. Put another way, the volume of Alberta's bitumen resource exceeds by more than one hundred times the total of all light-medium crude oil produced in Alberta up to the end of 1998. There is one indisputable fact: Alberta's bitumen resource is enormous.

While this may be so, commercial recovery of that bitumen has proven to be a challenge. This is particularly true for in situ bitumen, in respect of which a number of technologies have been employed with relatively modest commercial success. Commercial production employing SAGD technology commenced in earnest only in 2002. Because of the relative novelty of the $S A G D$ production method, significant uncertainty remains concerning whether and to what extent commercial SAGD bitumen production will be successful. The potential for SAGD developmert in the Athabasca Oilsands area has attracted a number of potential developers that have apparently concluded that the potential rewards are worth the risk. The AEUB certainly shares this optimism. It has forecast that the 2001 in situ bitumen production 
volumes of $49.210^{3} \mathrm{~m}^{3} / \mathrm{d}(310,000 \mathrm{bbl} / \mathrm{d})$ will more than double to $12610^{3} \mathrm{~m}^{3} / \mathrm{d}(790,000$ $\mathrm{bbl} / \mathrm{d})$ by $2011 .{ }^{44}$ Most of these new in situ projects, either announced or under construction, are expected to employ SAGD technology. The magnitude of the bitumen resource and the importance of that resource to Alberta's future as an energy producer provides a strong foundation on which to conclude that the AEUB is likely to continue its very conservative approach towards any gas production that may put bitumen recovery at risk.

Not all of the bitumen can or will be produced using SAGD technology. The quality of the available bitumen resource that is likely to be amenable to in situ recovery methods as a result has been the subject of considerable debate. In the Inquiry Report, the AEUB rejected the argument that there are ample alternative sites for bitumen producers to develop where they would not be in conflict with gas producers. ${ }^{45}$ In the 2000-22 proceeding and again in the 2003-023 proceeding, substantial debate centred over what quantity and quality of bitumen encountered should warrant its being protected. In response to the various submissions the AEUB stated that

there is insufficient understanding of the capabilities and limitations of SAGD at this time to definitively eslablish a bitumen pay criteria. Therefore, until more information becomes available, the [AFUB] believes that it should continue to use the criteria oullined in Interim Directive (ID) 99-I (i.e., $10 \mathrm{~m}$ or more of sand with bitumen saturation equal to or grealer than 50 per cent pore volume for the Wabiskaw-McMurray). ${ }^{46}$

Although this would seem to provide a factual cut-off in terms of what the AEUB is likely to consider for protection, the 2003-023 decision tends to suggest that the more significant question is whether gas is likely to be associated with any bitumen deposit whatsoever, regardless of the potential for commercial development of the bitumen deposit. This is a significant distinction. While some very thick and highly saturated bitumen deposits in the Chard-Leismer/Surmont area exist, there are also areas where bitumen deposits, though present, are of relatively poor quality. The uncertainty or lack of factual evidence concerning either the quantity or quality of bitumen resources in any given area has led the AEUB to employ a regional, rather than a deposit-specific, approach to assessing where potentially commercial bitumen may exist.

\section{ThE NATURE OF THE WABISKAW-MCMURRAY GLOLOGY}

While a huge amount of knowledge exists and a mountain of evidence has been directed to the AEUB regarding the geology of the Wabiskaw-McMurray Formation in various portions of the Athabasca Oil Sands Deposit, very little consensus and even fewer established facts exist in terms of the actual geology. The factual information derived from core, well log and open pit mine data has been used to draw inferences as to the depositional environment in which the geological structure was created and to interpolate between data points. 
To appreciate the gas/bitumen debate, it is neccessary to understand what is now the base issue: the Wabiskaw-McMurray depositional environment that has been the subject of the geological debate.

The Wabiskaw-McMurray zones, particularly in the Chard-Leismer/Surmont areas, were deposited over a span of several million years in a variety of fluvial (river), estuarine (delta) and shallow marine environments. In general, it is thought that sand and mud sediments derived from a land mass in the southwest of the area were carried by water towards a shallow sea in the northeast of the area. Over the period of deposition, both the sea level and the location of the coastline fluctuated continually. When the sea level went up (transgressed), the coastline moved up the land mass to the southwest. When the sea level went down (regressed), the coastline moved down the landmass to the northeast. While innumerable transgressions and regressions occurred in Wabiskaw-McMurray over time, the overall trend was towards a gradual deepening (transgression) of the shallow sea throughout this period.

This leads to a fairly typical opinion that when surface water flows from a land mass into a sea, the water has its highest energy at its highest point on the land mass, and that this energy gradually diminishes as the water moves towards the sea. The higher energy levels allow water to carry heavier sediments such that at high elevations, the water carries a mixture of lightweight mud particles and heavier sand particles. As the water moves towards the sea, it progressively loses the ability to carry heavier particles. The heavier particles drop out of the water and are "deposited." As the water moves further towards the sea, progressively smaller and smaller particles are deposited until the smallest of the particles (mud particles) are deposited onto the seabed. It is generally thought that these "marine" mudstones have the greatest likelihood of providing a pressure seal between gas and bitumen bearing zones in the Wabiskaw-McMurray section.

While this description may be one that most geologists accept, it is notable that it provides very little in the way of factual information about what might actually be expected at any given point or in any given area in terms of the Wabiskaw-McMurray geology. What may exist between data points and even at data points is largely a matter of interpretation. Particularly difficult in the context of inarine mudstones is the assessment of exactly how and where those mudstones were deposited and whether, after deposition, those mudstones were breached by high-energy water channels that deposited sand where mud had previously been (thus creating a pathway for gas/bitumen pressure communication).

The geologic rock formations found in the Wabiskaw-McMurray zones in the ChardLeismer/Surmont areas generally consist of complex layers of interbedded sandstones and mudstones. Sandstones generally have relatively high permeability and porosity and are considered to act as both reservoir rock and as conduits for fluid now and pressure communication between bitumen, natural gas and water. Mudstones generally have relatively low permeability and porosity and are considered to be cap rocks for gas reservoirs that will either impede or completely block the flow of, and pressure communication between, bitumen, gas and water. 
Complicating this is the fact that much of the Wabiskaw-McMurray area consists of either sandy mudstones or muddy sandstones, both of which can be interpreted as either conduits of fluid flow and pressure communication or impediments or as complete seals to fluid flow and pressure communication. The Wabiskaw-McMurray mudstones have been the subject of vigorous debate, particularly in the context of the ability of those mudstones to isolate bitumen deposits from overlying gas and water-bearing zones. Much of the geological discussion in the 2000-22 proceeding, for example, hinged on the geological identification and existence of an inclined heterolithic stratification (IHS), which was said to exist in every cored well at Surmont. ${ }^{47}$ It was contended that IHS would practically slow steam rise so that breakthrough of the steam chamber to a depressured overlying gas or water zone would be unlikely to occur at all and, in any event, not in a timeframe that would negatively impact SAGD operations. The AEUB rejected this contention on the basis that IHS beds are typically thin and likely to be discontinuous. The AEUB additionally accepted the hypothesis that high permeability channel sands might cut through the IHS, thus providing a chimney"s for rapid steam rise into overlying gas or water zones.

Like so many factual issues in the gas/bitumen debate, the question of whether mudstones might provide pressure isolation between gas and bitumen zones is indeterminate at best. Given this uncertainty and the high priority that the AEUB places on protecting the bitumen resource, the AEUB determined that, unless pressure separation between gas and bitumen zones can be established with a high degree of certainty, gas production should not be allowed. In its 2003-023 decision, the AEUB did recognize the presence of a limited number of "marine" mudstones, which the AEUB considered might be sufficiently continuous over extended areas to provide the higher degree of certainty that pressure isolation exists as between gas and underlying bitumen. ${ }^{49}$

\section{The Potential. for Pressure COMMUNiCATION}

ID 99-1 requires that prior to receiving approval to produce gas from oil sands strata, a producer must show that it is not associated gas. ID 99-1 defines "associated gas" as follows:

Associated gas refers to gas that is in pressure communication with bitumen within the region of influence either directly or through a connecting water zone. The region of influence is taken to be the extent of the gas pool in the case of gas directly overlying bitumen or the combined extent of the gas pool and water zone in the case of gas overlying water overlying bitumen. ${ }^{\text {so }}$

A critical first step in establishing whether gas is associated gas is the determination of whether gas pools are or are likely to be in pressure communication with underlying bitumen deposits. Absent evidence of direct gas-bitumen communication observed in a wellbore, the question of whether pressure communication exists at some point other than at a wellbore is largely dependent on an inference drawn from a geological interpretation and pressure data.

4) Supra note 2 at 19.

\$* "Chimney" is a term used to describe sand on sand contacts that provide a direct path for steam to rise through the bitumen zone.

"See infra note 137.

Supra note 8 at 2. 
Besides direct gas-bitumen communication, the AEUB also recognized the possibility of pressure communication occurring through a water zone that underlies a gas zone. Accordingly, even if a gas pool is relatively small, that pool's region of influence may be extended by virtue of the presence of an underlying aerially-extensive water zone. In addition, several small gas pools may be considered to be in pressure communication with each other through an aerially-extensive water zone. While water has been encountered in many of the wells in the Chard-Leismer/Surmont area, it is practically impossible to determine the aerial extent or other physical proximity characteristics of these water zones with any certainty. In the 2000-22 decision, the AEUB acknowledged that

[i]t is difficult, perhaps impossible, to establish the actual size and shape of the regions of influence in the Surmont area with the available data and knowledge about the geometry, heterogeneity, and properties of the Wabiskaw-McMurray gas pools and aquifer and without clear scenarios for gas production and bilumen development. ${ }^{51}$

Nevertheless, the AEUB concluded in the 2003-023 decision that, while McMurray channel sand gas pools are typically quite small (two to three sections), underlying water zones are likely to be much larger (eight sections to two townships in size) and are typically in communication with more than one gas pool..$^{32}$

\section{The Use of Pressure Data}

Pressure data is normally thought of as a powerful tool for geologists and reservoir engineers to delineate the physical characteristics of gas reservoirs. Natural gas follows the physical laws respecting the interrelationship of gas pressure, volume, temperature and quantity. Accordingly, by measuring temperature, pressure and produced gas quantities over time, a reservoir engineer can gain an understanding of the size of the reservoir and whether it is in pressure communication with, or isolated from, surrounding gas pools and water zones. In addition, pressure measurements taken at different depths in a single wellbore can indicate whether different zones encountered by the wellbore are in pressure isolation from one another.

There is, in the gas/bitumen context, little or no reliable factual evidence to establish conclusively pressure separation. This is in part due to the relative paucity of pressure data from segregated zones. In addition, this is also partially due to the questionable quality of much of the pressure data and the pre-measurement depressured state of many gas wells. Also, there is the view that bitumen itself, under reservoir conditions, might be expected to act as a barrier to pressure, but that such a barrier may not exist when the bitumen is exposed to thermal conditions from a SAGD steam chamber. The AEUB has identified similar concerns with respect to thin shales or mudstones that also might be construed to be barriers under reservoir conditions. ${ }^{53}$ As a consequence, pressure segregation practically can be established only to the degree that is likely to satisfy the AEUB by means of a geological interpretation. The AEUB has indicated that where gas and bitumen are separated by marine 
mudstones that can be consistently correlated over large areas, the AEUB is prepared to accept that pressure communication between the gas and the underlying bitumen is unlikely to occur. Conversely, if mudstones are discontinuous and cannot be correlated over large areas, or if there is evidence of mudstones having been cut by sand channels, the potential for pressure communication is likely to be assumed.

Initial and annual pressure monitoring is required with respect to gas wells in Alberta. ${ }^{54}$ In addition, some bitumen developers have begun installing piezometers in observation wells. As well, gas producers, bitumen owners and the AEUB have, for some time, been collaborating outside of the formal hearing process to share pressure information and develop processes for pressure monitoring. In the 2003-023 decision, the AEUB encouraged gas producers and bitumen owners to develop and implement cooperatively a pressure monitoring program acceptable to all parties. ${ }^{3 s}$

\section{SAGD DATA}

Due to the limited amount of directly applicable field data, the AEUB has relied heavily on numerical modelling (computer simulations) to predict SAGD performance under different gas production scenarios. While numerical modelling may provide the best available evidence, the absence of relevant field data to calibrate numerical models tends to call into question the validity of numerical modelling results. The absence of any real world calibrations also tends to explain the significant divergence of modelling results that have been presented in various AEUB proceedings.

All of the gas/bitumen proceedings have included a review of available field studies. These include studies of non-SAGD bitumen steam floods in Alberta at Kearl Lake and Cold Lake, steam floods in conventional oil fields in different parts of the world, and actual SAGD test studies performed at the Underground Test Facility (UTF or Dover) in northeastern Alberta. None of this field data represents an accurate analog for the gas/bitumen issue, particularly as the issue is complicated by water zones that might underlie the gas. The AEUB has selectively relied on some of this field data and has selectively rejected other data. The AEUB, for example, agreed that the Kearl Lake pilot provides a field example of the negative effect that a low pressure thief zone ${ }^{36}$ can have on a gravity-dominated steam injection process. ${ }^{57}$ Although the Kearl Lake gas zone was effectively repressured, the AEUB rejected Kearl Lake as an analog for repressuring at Surmont due to geological differences." Similarly, the AEUB rejected evidence about the impact of IHS on the extent of steam rise observed at the Dover Phase B pilot to determine the potential extent of steam rise at Surmont, also for the reason that the geology at Dover was not considered analogous to that at Surmont. ${ }^{\text {s9 }}$

Pressure and Deliverability Testing Oil and Gas Wells (May 1999) AEUB Guide 40. online: AEUB <wnw.eub.gov.ab.ca/BBS/requirements/Guides/g40.hım>.

" Supra note 4 at 38.

*. A zone into which heat or pressure is likely to be lost, such as to a water zonte or to a depressurized gas zone. 2000-22, supra note 2 at 67.

lbid.

lbid. at 21. 
Considered by some parties to be of greater relevance to SAGD performance in the context of the gas/bitumen issue is the field data associated with the ConocoPhillips Canada pilot SAGD project at Surmont. Although the Surmont project has been operational for a number of years, performance data from the project remains confidential and, therefore, has not been available to the public to assist with the issue. Commercial SAGD projects that are currently proceeding at Christina Lake (located in the Leismer area), Foster Creek (located to the South of the Chard-Leismer area), McKay River and other projects that are expected to be developed within the next few years, may provide some greater insight into the effectiveness of commercial SAGD operations. However, only the Christina Lake project is likely to provide any early field experience with respect to the issue of top gas and a zone of depleted pressure.

\section{SAGD MODELIING}

Numerical modelling involves the use of computers to simulate the expected production performance of an oil, gas or bitumen reservoir. In the gas/bitumen context, numerical modelling is used to predict the impact of associated gas production on SAGD performance. Development of a SAGD numerical model is a complex process that involves the manipulation of various types of inputs, including:

- physical characteristics (viscosity, porosity, permeability, water saturation, etc.) of the sand, rock and reservoir fluid to be modeled;

- facilities configurations and capacities (location of SAGD well pairs, steam generation capacity, etc.); and

- scientific laws respecting fluid flow in oil and gas reservoirs.

Numerical modelling is typically an iterative process where an initial set of inputs is manipulated and modelling results are "history matched" against the actual performance of a producing reservoir. Modelling inputs are then adjusted and the model re-run and history matched again. This iterative process continues until a satisfactory match is achieved between the model and the historical performance of the reservoir.

The absence of SAGD field data in the context of a top gas zone eliminates the ability of numerical modellers to perform the history-matching process. This has resulted in a significant divergence of the models presented to the AEUB and has raised significant doubt as to which, if any, of these models reflects the actual SAGD performance that might occur in the field. The AEUB, though, has consistently recognized that

there are uncertainties with using reservoir modelling to evaluate the effect of associated gas production on SAGD recovery. While having a model that has been history matched to field data would provide more confidence in the evaluation, there are limited field data available from the Surmont pilot. Although additional field data are continuing to be obtained from the Surmont pilot, the [AEUB] believes that it is not acceptable in wait for this additional field data ... becnuse waiting would involve a signifiennt risk to bitumen recovery. ${ }^{60}$ 
In the 2003-023 proceeding, the AEUB examined the different approaches utilized to generate SAGD models, which it characterized as either generic or well-specific. The generic model is of a conceptual nature that may reflect field geological, petrophysical and core data, but that does not mirror any single reservoir. Well-specific models, on the other hand, tend to be developed using the geological and petrophysical data extracted from one or a few specific wells. In respect of these approaches, the AEUB concluded: "Considering the complex nature of the Wabiskaw-McMurray, the AEUB believes there are limitations with both approaches, and the AEUB certainly heard considerable debate about the geological descriptions used in the model studies." ${ }^{11}$ The AEUB noted that some models included a breakthrough column ${ }^{62}$ that is subject to interpretation and that adds to model uncertainty. ${ }^{63}$ The AEUB also noted that some elements included in models can be easily implemented in a model but would be difficult, if not impossible, to implement in the field. ${ }^{64}$

Notwithstanding the uncertainties associated with the models put before the AEUB, the AEUB concluded that it must continue to rely on modelling to evaluate the issue. On that point, the assessment was "that producing gas that is associated with bitumen ... presents an unacceptable risk to SAGD bitumen recovery." ${ }^{\circ 5}$

\section{B. Tranology}

Technological issues have been at the forefront of all of the AEUB's gas/bitumen proceedings. Of these, several technological issues warrant comment in terms of the potential they hold for the future of the gas/bitumen issue. These include:

- SAGD technology;

- gas zone repressurization;

- artificial lift; and

- low pressure SAGD.

\section{SAGD TECHNOLOGY}

Although the SAGD technology has been the subject of some debate, it appears to be accepted as technically proven with commercial potential. In the Inquiry Report, the AEUB concluded that "SAGD, presently offers the greatest promise for the eventual development of Alberta's in siru oil sands resources." portion of all of the hearing records so far conducted relates to the nature and quality of the reservoir parameters within which SAGD might be employed. Most of the newly-established commercial projects have been established in areas where the bitumen zone is both thick and continuous and where the sand has a high pore volume bitumen saturation.

2003-023, stupra note 4 at 31.

Refers to sand on sand contacl, such as a chimney, which provides a high permeability routc for steam to rise through the bitumen zone.

Supra note 4 at 32.

ibid.

lbid. at 33.

Supra note 9 at 46. 
In the 2003-023 proceeding, it was argued that only bitumen that clearly meets criteria of commercial quality should be considered for protection. The AEUB indicated that it agreed with "the general consensus of the hearing participants that only the bitumen that meets certain basic cutoffs and parameters should be considered as being worthy of protection." The AEUB, however, did not accept the view that commercial criteria should be applied at the stage when the bitumen resource is being prospected and delineated. To do so, the AEUB concluded, could result in significant bitumen resources being inappropriately designated as unworthy of protection prior to being assessed properly. ${ }^{88}$ As there exists at this time insufficient understanding of the capabilities and limitations of SAGD to establish definitively a bitumen pay criteria, the AEUB concluded that it will continue to use the criteria outlined in ID $99-1$ until more information becomes available. ${ }^{69}$

In the context of this prospecting criteria, as settled by the AEUB, there would appear to be little potential for more information to be of much value, although a commercial criteria might prove to be substantially different. The prospecting criteria is arbitrarily established to provide a level of insurance against being wrong.

\section{GAS ZONE REPRESSURIZATION}

In each gas/bitumen proceeding it has been argued that even if depletion of a gas zone should eventually be shown to negatively impact SAGD recoveries, this concern can be addressed by repressuring the gas zones (with natural gas or perhaps with other substances such as $\mathrm{CO}_{2}$, nitrogen or flue gas) at the time that a SAGD project is developed.

The AEUB has consistently rejected the concept of gas zone repressuring as a current solution to the gas/bitumen issue. Although the evidence presented to the AEUB has shown ample successful repressurizations of gas and oil reservoirs, the AEUB has rejected repressurization as a mitigation measure because its viability has not been proven in respect of the gas/bitumen issue. The AEUB identified specifically that gas zone depletion may result in changes to the physical characteristics of both the bitumen and the reservoir which may not be reversible by repressurizing. In addition, the AEUB expressed concern about the possibility of gas "leak-off" through extensive water zones or otherwise during repressuring.

While the AEUB has concerns regarding the viability of repressuring, it acknowledges in the 2000-22 decision that if shown to be viable, repressurization may be a reasonable burden to place on a bitumen developer:

If the [AEUB] were reasonably convinced that reservoir pressure could be restored to virgin conditions at some point in the future, it could take the view that depleting the gas pools now would not be an irreversible burden to impose on future bitumen producers. Therefore. the [AEUB] could leave it to future investors to come up with the equivalent of 200 Million in gas (or some other medium) to repressure the pools if repressuring were considered to be a low-risk option. This would not be an unfair burden to impose on a future generation. It percent pore volume). 
would not be much more expensive for them to incur the cost of repressuring than it would be for these costs to be incurred today by shutting in gas production indefinitely. However, this alternative is largely academic. since the [AEUB] is not convinced that repressuring with gas, or any other medium, is viable. ${ }^{70}$

The AEUB did not view Surmont as an acceptable place to rely on repressuring because of the possibility of gas leak-off through aerially extensive water zones. However, in the Chard-Leismer proceeding, the AEUB showed more willingness to accept repressurization on a limited basis. In that proceeding, EnCana Corporation (EnCana) and Devon Canada Corporation (Devon) announced they had entered into an agreement respecting repressurization of a Devon gas reservoir in the vicinity of EnCana's Christina Lake SAGD project. Under the agreement, Devon was effectively allowed to deplete the gas zone and thereafter, EnCana could then take ownership of Devon's gas infrastructure for the purpose of repressuring the gas reservoirs with flue gas. On the strength of this repressuring agreement, the AEUB allowed Devon to continue gas production from one of the single well gas pools proposed for repressuring while ordering the shut-in of other associated gas production in the vicinity of the EnCana Christina Lake SAGD project.

\section{ARTIFICIAL LIFT}

Once bitumen drains into the horizontal wellbore of a SAGD project, there must be some means to lift the bitumen up the wellbore to the surface. Where the reservoir pressure is high enough, bitumen will flow to the surface unassisted. This is called "gas lift." Evidence before the AEUB in the 2000-22 and 2003-023 proceedings suggested that gas lift was no longer practical at reservoir pressures in the range of 1,650 to $2,000 \mathrm{kPaa} .{ }^{7}$ At lower reservoir pressures, other lift mechanisms, such as electric submersible pumps (ESPs), would need to be installed in the wellbore to push bitumen up to the surface. This is called "artificial lift."

ESPs have long been used in applications around the world, but have only recently been employed in SAGD operations, where ESP performance in the specific environment of temperature, pressure and sand conditions remains largely untested. ${ }^{72}$ Due to the paucity of SAGD field experience generally and with ESPs in particular, a significant amount of debate since 1998 has taken place in terms of the potential capability of ESPs. The AEUB, in that regard, expressed concerns that if reservoir pressures get too low (in the 400-600 $\mathrm{kPaa}$ range or below), even ESPs would not be technically feasible. ${ }^{73}$

\section{LOW PRESSURE SAGD}

At the 2003-023 hearing, evidence was presented regarding the possibility of operating SAGD projects with very low associated gas pressures. Proponents of low pressure SAGD argued that numerical modelling showed that low associated gas pressures would actually enhance the efficiency of SAGD while improving economics due to reduced steam requirements. In the 2003-023 decision, the feasibility of low pressure SAGD was considered

\footnotetext{
St1 Supra note 2 at 82.

"2003-023. sipra note 4 at 48.

32 EnCana was the first to use an ESP in a SAGD application at its Foster Creek SAGD facility in early 2002.

2003-023, supra note 4 at 35
} 
only obliquely by the AEUB in the context of the feasibility of artificial lift criteria. There the AEUB concluded that

the risks associated with SAGD bitumen production increase at lower operating pressures. As a result, the [AEUB] continues to believe that where gas is associated with bitumen, gas zone depressuring should be kept to a minimum to better ensure successful $S A G D$ operations in terms of resource recovery and minimizing the technical difficulty of lifting $S \wedge G D$ nuids. ${ }^{74}$

Currently, the concept of low pressure SAGD is being studied further by a joint industry/ government technical committee. Low pressure SAGD, if widely accepted by bitumen producers, could hold the potential of being a complete answer to the gas/bitumen issue.

\section{Policy}

The policy that currently applies to the gas/bitumen issue is that which evolved out of the Inquiry Report and was embodied in ID 99-1. A number of other policy approaches also have been raised with the AEUB. While none of the approaches have been accepted yet, some appear to be the subject of ongoing consideration and even the policy reflected in ID 99-1 appears to be under consideration for revision.

\section{NO FLY ZONE}

The approach of identifying areas for special attention has been contemplated in several different respects.

In the Inquiry Report, it was argued that there were ample alternative sites for bitumen producers to develop where they would not be in conflict with gas producers. The AEUB rejected such an approach because "the logical implication of this argument is that some potentially recoverable bitumen resources are expendable in the interest of near-term gas production." 75

In the 2003-023 proceeding, it was suggested that the area of potentially high-risk bitumen recovery should be delineated and that all gas production within the defined area should be suspended. Such suspension would continue until it could be reasonably established that producing the gas would not jeopardize the recovery of the bitumen. This approach was predicated on the perception that future evidence, presumably of a definitive nature, would be available to confirm the appropriateness or inappropriateness of producing the gas. So far, the AEUB has not accepted this approach.

The AEUB's reluctance to deal with the gas/bitumen issue on a broad and general basis appears to be waning. In the 2003-023 decision, the AEUB identified a trend area within which it observed rests "Alberta's most significant bitumen deposits" and within which most announced and approved commercial SAGD projects fall. ${ }^{76}$ In its decision, the AEUB also 
identified grandfathered gas production in the Chard-Leismer area and in other areas of the Athabasca Wabiskaw-McMurray deposit with a fluvial-estuarine depositional environment that could present a significant risk to future bitumen recovery. These non site-specific considerations suggest that the AEUB may intend a more general area-based focus.

The fact that the AEUB has not chosen to impose a blanket restriction on gas production suggests that it is, as a matter of policy, prepared to continue tolerating some level of risk to future bitumen recovery.

\section{MARKET MECIIANISMS}

In the gas/bitumen inquiry, the AEUB was urged to adopt a market mechanism to optimize resource recovery. It was suggested that bitumen producers be obliged to purchase the associated gas reserves that were considered to be an issue in respect of future bitumen recovery at fair market value. This, it was contended, would introduce some reality and practicality to the gas/bitumen issue. It was thought that if a bitumen prospect was not sufficiently attractive to warrant the purchase of the gas, bitumen producers would have the opportunity to move to any number of equally or more attractive bitumen resource areas where gas production and pressure depletion would not be an issue. The AEUB rejected this approach, in part, because it was based on the premise that oil sands leaseholders would actually protect their own oil sands interests. The AEUB expressed concern that the longterm interests of oil sands leaseholders might not be exactly aligned with the Alberta's longterm public interests. ${ }^{77}$ The AEUB determined that some regulatory involvement was warranted, at least until such time as additional information was available to clarify the effect of associated gas production on bitumen recovery or that alternative technology and/or economic circumstances could be shown to reduce the risk of bitumen sterilization. ${ }^{78}$

In the Inquiry Report, the AEUB indicated that it was not just physical waste that was at issue, but that economic sterilization was also an equally unacceptable risk. ${ }^{79}$ In the subsequent 2000-22 proceeding, the AEUB was encouraged to adopt an approach that would have made proponents of bitumen projects responsible for the veracity of their economic assessments. The AEUB rejected this approach, indicating that if it followed this recommendation, it might be led to ignore many situations where resources could be effectively sterilized. This, the AEUB said, "would not be in keeping with the [AEUB's] mandate." 80

In the 2003-023 proceeding, the presiding panel member queried: "but when I think about the inquiry and Surmont and the interim hearing and this hearing, I really wonder what we are accomplishing in terms of being able to get parties together on a technical basis. We are as far apart as ever, maybe further apart." ${ }^{81}$ In its 2003-023 decision, the AEUB noted that "the earlier Gas/Bitumen Inquiry and Surmont hearing were similarly long, complex, adversarial, and acrimonious." The AEUB went on to indicate that it

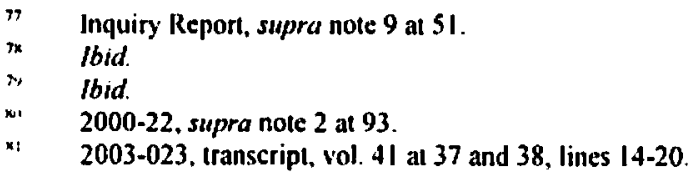


believes there are two features that make a commercial resolution of the gas/bitumen issue diflicult. First, there is an absence of well-informed economic analysis. Second, under the current legislation, a [AEUB] decision either to shut in gas production or allow it to be produced has the potential to give one of the parties an advantage in negotiations. ${ }^{82}$

The AEUB, it seems, is little inclined to overcome these difficulties or to consider an approach that would maintain its regulatory oversight while at the same time provide an incentive for parties to establish technical or commercial resolutions. The AEUB, in its Inquiry Report and in the context of its 2000-22 decision, rejected the concept of commercial arrangements to resolve disputes as between gas and bitumen owners in favour of a regulatory disposition of the conservation concern. That approach is reinforced in the 2003023 decision where the commercial arrangement/resolution established between Devon, the gas owner and EnCana, the bitumen owner, in the Christina Lake area was implicitly rejected. This rejection, however, was with the exception of a single well pool in which a repressurization scheme had been proposed. The AEUB's perception of its role under the current legislation as limited to deciding to shut-in or to allow gas production is also somewhat surprising. The very broad and general conservation and public interest mandate on which the AEUB predicated its authority to deal with the gas/bitumen issue ${ }^{83}$ could, arguably, permit a more comprehensive approach to be taken.

\section{LAND TENURE}

In the gas/bitumen inquiry, it was argued that the split rights issue was a significant cause of the gas bitumen debate and that elimination of the split rights to the oil sands zones would go some distance towards minimizing the significance of the issue. In the Inquiry Report, the AEUB observed that "the current lease tenure system where P\&NG rights are leased separately from the oil sands rights presents a number of regulatory conflicts that need to be resolved." $8+$ The AEUB went on to indicate that it would support modifications to the existing lease tenure system in the oil sands areas to reduce resource development conflicts.

Notably, it appears that this was a matter that might have been within the purview of the AEUB to modify implicitly had it so desired. A 1983 amendment to the Mines and M/inerals $A C t^{85}$ reinforced the definition of oil sands as not including natural gas, but also was made to include a hydrocarbon substance declared to be oil sands under s. 7(2) of the Oil Sands Conservation Act. ${ }^{86}$ The AEUB has, pursuant to that authorization, named the strata and geographic areas that were considered oil sands, but has not taken the opportunity to declare natural gas, as a hydrocarbon substance, 10 be oil sands.

The Alberta Department of Energy has advised that "natural gas rights in the oil sands zones in Application Areas set out in AEUB Interim Directive ID 99-1 and subscquent and

See supra note 2, at Appendix 8, where the AEUB concluded that "it has the statutery duthornty to hear the application and take whatever action witlin the [ALUB s] jurisdiction, as cutlined above, it deems necessiary." 
future amendments ... will be reserved from disposition and not be issued through public or private sales processes." ${ }^{87}$ This policy initially was put into place for a two-year period but the restriction subsequently has been extended to an indefinite term. ${ }^{38}$ Little else has been done to address the split rights issue as either a means of addressing ownership issues or a means of mitigating conservation concerns. However, in its most recent decision, the AEUB reiterated that the existing shared ownership regime makes a resolution extremely difficult. ${ }^{89}$

The measures by Alberta Energy tinkering should ensure that the tenure issue is not exacerbated. However, the alignment that has existed over the years between the mineral tenure and regulatory regimes continues to be out of alignment and, as the AEUB has noted, is an ongoing difficulty.

\section{COMPENSATION}

In the gas/bitumen inquiry, some gas producers urged that, if that existing associated gas production was curtailed, some form of compensation would be warranted. With respect to this claim, the AEUB noted that "these matters would need to be resolved with the Provincial Government." shut-in of Surmont gas reserves would result in a significant impact on gas producers that could lead to some complementary action. This action presumably referred to potential steps that could be taken by the provincial government. The AEUB noted that it was open to the Lieutenant Governor-in-Council to direct the AEUB to prepare a scheme to compensate persons who are injured or who suffer a loss by reason of any orders made pursuant to the Oil and Gas Conservation Act."

The idea of compensation being paid, particularly by bitumen owners, was opposed by some of those owners on the basis that the payments in such circumstances is unusual and unnecessary. This is particularly so where gas cap production has historically been precluded from conventional oil pools without payment of any compensation.

Following the shut-in order issued by the AEUB for wells in the Surmont area, the Lieutenant Governor-in-Council, at the urging of the affected gas producers, directed the AEUB, pursuant to what was then s. 91 of the Oil and Gas Conservation $\mathrm{Act}^{92}$ to

prepare a sclieme or schemes for the provision of compensation for persons, not including the Crown, having an interest in the production and natural gas rights effected by the Order and who are injured or who suffer a loss as a result of the Order, by those persons not including the Crown, the [A]EUB determines should pay such compensation. ${ }^{93}$

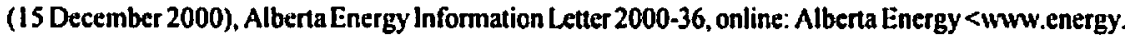
gov.ab.ca/com/room/industry+room/ industry+updates/information+letters/2000/2000-36.htm $>$. (25 February 2002), Alberta Energy Information Letter 2002-07, online: Alberta Energy <www.energy. gov. ab.ca/com/room/industry+room/industry+updates/information+letters/2002/2002-07.htm>. Supra note 4 at 53.

Supra note 9 at 52

Supra note 16. See discussion of the Lieutnant Governor's discretion in 2000-22, supra note 2 at 84 Ibid:; R.S.A. 1980, c. O-5.

OlC 196/2000, online: Government of Alberta <www.gov.ab.ca/home/Orders_in_Council/2000/500/ 2000_196. html> [OIC 196/2000]. 
OIC 196/2000, which excluded the Crown from any opportunity to receive or any obligation to pay compensation, was of concern to bitumen, petroleum and natural gas rights holders. For bitumen owners, the finger was pointed squarely at them as the potential sole payors. OIC 190/2000 was of equal concern to the shut-in gas producers. As the AEUB had in both the Inquiry Report and the 2000-22 decision rejected an approach of requiring bitumen owners to purchase the gas rights, full compensation under the terms of the OIC 190/2000 would have effectively produced the very result the AEUB had rejected as inappropriate. The gas producers were concerned that this might leave the AEUB cornered into preparing a scheme for token compensation only.

The bitumen producers that had been active in the 2000-22 proceeding challenged the validity of OIC 190/2000 in proceedings before the Alberta Court of Queen's Bench. ${ }^{94} \mathrm{OIC}$ 190/2000 was struck down as ultra vires for reason that the Lieutenant Governor-in-Council was not authorized to impose conditions on its direction. OIC 190/2000 was not reestablished.

A compensation agreement was subsequently reached between the Crown, Gulf and the Surmont gas producers generally based on a sharing of the burden. The agreement allowed the Surmont gas producers to recover approximately two-thirds of the value of the shut-in gas, the cost of which was to be borne by the Crown and the bitumen producer. The agreement provided for the compensation to be paid by way of a royalty credit against other existing oil sands gas production. The Crown also agreed to advance the share required to be paid by the bitumen producer through a royalty credit and agreed to recover that advance from increased bitumen royalties in the future after the payout of the bitumen project. As an incentive to ensure that commercial bitumen production occurs, various milestones were established in the agreement between the bitumen producer and the Crown which, if not met, would result in the forced surrender of portions of the leased bitumen rights.

\section{INTERIM DIRECTIVE $99-1$}

The current policy as established by ID 99-1 appears to be in the process of being revised, if not expressly, at least implicitly. The existing policy, as it evolved out of the Inquiry Report, acknowledged that it could result in financial hardship to gas producers who initiated their activities with the expectation that gas production would be allowed." This led the AEUB to the view that it should, in faimess, specifically consider gas operators who drilled wells and installed facilities in good faith with the reasonable expectation that gas production would be permitted. Having regard to this consideration, the AEUB accepted that the approach of grandfathering established production might have some impact on future bitumen recovery. However, it was prepared to allow associated gas production from investments made up to 1 July 1998 to continue unless on a complaint or on the basis of the AEUB's own motion it was shown that such allowances would not be in the long-term public interest. ${ }^{96}$ 
The balance between fairness and conservation is something that the AEUB appears to have decided to revisit. In the 2003-23 decision, with respect to wells not specifically considered at the hearing, the AEUB indicated that

the [AEUB] believes that some of the gas being produced by these 117 wells. shown in Appendix 3, could present significant risk to future bitumen recovery. The [AEUB] also believes that some grandfathered gas production in other areas of the Alhabasca-Wabiskaw-McMurray deposit with a depositional environment similar to that at Chard-Leismer (i.e., fluvial-estuarine) could present a significant risk to furture bitumen recovery. Therefore, the [AEUB] believes that there is a need to develop and implement a process to address grandfathered gas production ... and it intends to pursue this matter. ${ }^{97}$

Notably, none of the AEUB's rethinking with respect to grandfathered gas production relates to a complaint or to a substantive reason why the balance, to reflect fairness, established in 1998, is no longer appropriate.

On a similar basis, the AEUB concluded that it should also review some of its own postI July 1998 decisions that granted approval to produce Wabiskaw-McMurray gas. ${ }^{98}$ The AEUB appears now to be moving towards a policy that will reflect only conservation considerations based on geological interpretation. This policy will apply with respect to both new and established gas wells in the Athabasca Oil Sands Deposit.

The AEUB has recently invited submissions from interested parties on the questions of whether other existing gas production from Wabiskaw-McMurray zones in the Athabasca Oil Sands Area should be shut-in and as to any alternative measures that might be taken to ensure the conservation of bitumen in the Wabiskaw-McMurray. ${ }^{90}$ This tends to confirm that the AEUB's initially-established policy with respect to grandfathered gas production is likely to be revised, notwithstanding the determination made by the AEUB in the 2003-023 decision that " $[t]$ he $[A E U B]$ does not find the evidence submitted to this proceeding to be sufficiently complete and conclusive to indicate what, if any, changes to ID 99-1 are warranted. Therefore, the AEUB continues to believe that the current application process is appropriate to ensure that potentially at risk bitumen is not jeopardized." 100

The policy initially established as ID 99-1 would appear to be on the verge of one other significant, albeit implicit, revision. In the gas/bitumen inquiry that led to ID 99-1, the AEUB indicated that it had considered the establishment of criteria to narrow the scope of a concurrent production requirement, such as defining geographical areas of interest or a minimum bitumen pay thickness. The AEUB, though, concluded that it would be premature to identify such criteria, as they would be quite arbitrary. Rather, it concluded that "each case where bitumen recovery is potentially at risk from associated gas production would be considered on its own merits." 101 
Under the criteria established by the AEUB in its 2003-023 decision, merit considerations applied to individual bitumen deposits on a case-by-case basis appear to be giving way to more broadly-based general considerations. This is embodied in the current approach, which seems to be moving toward such considerations as:

- the fact that Wabiskaw-McMurray bitumen resources in the Chard-Leismer area represent a trend with Alberta's most significant bitumen deposits; ${ }^{102}$

- the use of a minimum bitumen pay criteria (ten metres or more of sand with bitumen saturation equal to or greater than $\mathbf{5 0}$ percent pore volume for the WabiskawMcMurray), denoted as a prospecting rather than a commercial criteria; ${ }^{103}$

- regions of influence that are generally pervasive in areas of McMurray channel gas; ${ }^{104}$ and

- the defined mudstone criteria, which the AEUB indicated it would accept as sufficiently definitive in terms of the existence or lack thereof of the potential for lateral and vertical pressure communication. ${ }^{105}$

It was on the basis of this approach, and particularly the interpreted presence or absence of certain "marine" mudstones, that the AEUB assessed whether the Wabiskaw-McMurray gas zones reviewed in the 2003-023 hearing were likely to be in pressure communication with underlying channel bitumen. ${ }^{106}$ These same criteria appear likely to be applied by the AEUB in its review of grandfathered and previously-approved gas production.

\section{Law}

Issues relating to the law remain important in terms of the way in which the gas/bitumen issue has unfolded and continues to unfold.

\section{JURISDICTION}

An initial issue was raised in response to the Gulf shut-in application at Surmont with respect to the jurisdiction of the AEUB to order the shut-in of producing gas wells for purposes of establishing a priority of production. At the time of the 2000-22 hearing, no specific legislative provision existed to authorize such action and the only requirements that reflected the policy that the AEUB had adopted were those set out in ID 99-1. The Surmont Gas Producers asked the AEUB to dismiss the Gulf application for want of jurisdiction to grant the relief requested by Gulf. The AEUB rejected the Surmont Gas Producers' jurisdictional arguments and eventually ordered the shut-in of a number of producing wells and zones within various wells. Leave to appeal the AEUB's initial determination of the jurisdictional issue was granted by the Alberta Court of Appeal prior to the commencement of the 2000-22 hearing, but the application was never pursued to a conclusion. 
The jurisdictional argument hinged on two primary elements. The first was the lack of specific authority of the AEUB to grant the relief on the grounds sought by Gulf. The second related to the concurrent production approval approach envisioned by the AEUB as being an unauthorized manner of regulation. The contention was that the regulatory approach established by the AEUB had the effect of re-enacting the gas/bitumen concurrent production approval provisions that had existed in the Oil and Gas Conservation Act and that had been repealed by the Alberta Legislature in $1983 .{ }^{107}$

The substantive arguments made to the contrary were that the AEUB had a very broad and general authority and an overriding mandate from the Legislature to regulate and ensure the conservation of Alberta's energy resources in the public interest. The AEUB had addressed its jurisdiction to regulate in this fashion in the Inquiry Report, where it indicated that

[t]he [AEUB's] broad conservation mandate, as set out in s. 2(c) of the ERCA, is "to effect the conservation of and to prevent the waste of the energy resourees of Alberta." More specifically, s. 3(b) of the Oil Sands Conservation Act (OSCA) establishes that one of the [A]EUB's purposes is "to ensure orderly, efficient and economic development, in the public interest of the oil sands resources of Alberta." A host of general provisions in the ERCA (ss. 2.1, 15,21 and 33), the OSCA (ss. 4, 5 and 6) and the Oil and Gas Conservation $A C /(O G C A)(s s .7,9,26,29$ and 86) further charge the $|A| E U B$ with the requisite broad authority to effect these purposes. ${ }^{108}$

The AEUB emphasized that "the conservation mandate was a founding purpose for the formation of the Petroleum and Conservation Board in 1938." 109 The expectation that arose from the Inquiry Report was "a framework for the creation of preliminary guidelines ... regarding the development of gas and bitumen in areas where it is determined a conflict exists between the production of the two resources." 110

So as to leave no doubt as to its position or resolve, the AEUB punctuated its intended approach by indicating that "[t]he [AEUB] will exercise jurisdiction over concurrent production involving oil sands pursuant to its general authority and seek legislative authority should the general authority be considered inadequate." "I" A similar position was reiterated by the AEUB in its ruling with respect to the jurisdictional challenge advanced by the Surmont Gas Producers. ${ }^{112}$

The legal debate over the AEUB's jurisdiction to shut-in producing gas wells at Surmont for purposes of establishing a priority of production never occurred. However, the issue was substantially determined in a collateral proceeding where most of the same parties participated and the same arguments were raised. In the collateral proceeding, ${ }^{113}$ the Court

The sections repealed would have clearly granted to the AEUB the specific authority to disallow associated gas production. The issue identified therefore was whether the AEUB had usurped the role of the Legislature.

Iin. Sirpra nole 9 at 4

(ii) Mid

11i. Ibid. it 4

III lbid. at 53

112 2000-22, supra note 2, Appendix 8.

11. This collateral case arose by way of an Originating Notice of Motion, which challenged the validity of the gas/bitumen concurrent production regulations established by the AEUB. 
of Queen's Bench rejected the challenge and confirmed the AEUB's authority and the validity of the regulations that had been placed in issue. The Court determined that the objects and stated purposes of the legislation made it clear that the prevention of waste and the conservation of resources go to the very root of the AEUB's purpose and existence. In addition, the Court held that the legislation expressly authorized the AEUB to establish regulations for those purposes.

An appeal of that decision was taken to the Alberta Court of Appeal. ${ }^{1 / 4}$ In dismissing the Appeal the majority found that

the [AEUB] is a specialized and expert tribunal charged with the administration of a comprehensive set of legislation regulating all aspects of the energy industry in the Province of Alberta. It is empowered to detcrmine issues ranging from those which are narrow and highly technical to those having broad and general implications not only for the industry but for the public. 115

The majority of the Court went on to indicate the appellant's subınission that no specific authority existed for the AEUB to enact these regulations

ignores the effect of the overall legislative framework within which sach of these statutes operate. This framework and the recognition by the individual statules of the potential impact of the development or management of one resource on other resources, even if provided for in separate statutes, makes it unnecessary to specifically provide that the [AEUB] may regulate concurrent production. When both provisions are considered within the Energy Statues framework, there is clear authorily for the [AFUB] to enact the impugned regulations. ${ }^{116}$

\section{Further, the Court noted that}

the Appellant's argument based on the repeal of sections 26(1)(f) and 29(2)of the OGCA in 1983 is unconvincing. While the repeal of these provisions may have removed the [AEUB's] authority to deal with concurrent production under the $O G C A$, the [AEUB] was given authority under the $O S C A$ that, when considered in the context of all the Energy Statutes. gives the [ $A \mathrm{U}(\mathrm{UB}]$ ] the same powers originally found in the now repealed provisions. 117

The majority of the Court of Appeal said, with respect to the AEUB's authority to make the regulations challenged, that "[ $t$ ]hese powers are necessarily incidental to the [AEUB's] responsibility for the conservation of energy resources in the public interest and to interpret the Energy Statues otherwise would be, in the words of the chambers judge, 'overly restrictive and completely at odds with the manifest intent of the legislation."'118

The minority's reasons substantially reflect and support the arguments that originally were advanced on behalf of the Surmont Gas Producers with respect to the lack of jurisdiction and

II. Giam Grosmont Petroleums v. Gulf Canada (2002), 93 Alta. I.R. (3d) 242 (C.A.).

"Is Ibid. at 255 quoting O'Leary J.A. in Coatition of Ciriz'ns Impercicd by the Carolme Shell Mlanss v Alberta (Energy and Uilities Board) (1996), 41 Alta. L.R. (3d) 374 (C A.) 
authority of the AEUB to shut-in the wells proposed for shut-in by Gulf. Leave to appeal to the Supreme Court of Canada was refused. ${ }^{119}$

Although there has been no direct judicial determination of the AEUB's authority to order the shut-in of gas production to effect a priority of production, there is authority that is quite compelling in terms of how that matter would be decided were the legal issue to be pursued.

\section{PROCLSS AND PROCEDURE}

The gas/bitumen issue continues to give rise to some novel process issues, some of which have already found their way before the Alberta Court of Appeal. ${ }^{120}$

\section{i. Confidential Proceedings}

In the 2000-22 proceeding, the AEUB initiated an in-camera session to obtain evidence of a commercial or sensitive nature over which several parties held proprietary rights. Specifically, the AEUB indicated that it

\footnotetext{
believed that information from the Dover steam-assisted gravity drainage (SAGD) experimental scheme and from the Gulf Surmont SAGD experimental scheme, then in the possession and/or control of participants before the [AEUB] and others, should be produced at the hearing. The parties possessing the information did not agree to produce it voluntarily, as it was commercially sensitive and had proprietary value. ${ }^{121}$
}

During the in-camera sessions conducted by the AEUB, only individuals that had personally executed confidentiality undertakings were permitted to be present. Those incamera sessions obviously presented a challenge to the AEUB's written decision, which included multiple notations of "confidential material removed," making some of the reasons difficult to comprehend. The complete decision, with all of the confidential material included, was and continues to be available only to those parties that provided a confidentiality undertaking.

Had an appeal of this decision been heard, it would have presented an interesting logistical challenge. However, as the appeal was not pursued, only a few people have had the opportunity to see the extent of the confidential evidence in the AEUB's decision.

From a practical and procedural perspective, the approach developed by the AEUB demonstrates that, in appropriate circumstances, the preservation and protection of confidentiality need not be a barrier to parties getting confidential material into evidence before the AEUB. After the 2000-22 proceeding, the AEUB established revised Rules of Practice that now contemplate oral hearings or portions thereof perhaps being closed to the public. ${ }^{122}$ 


\section{ii. Staff Evidence}

The 2003-023 proceeding saw the presentation of evidence by an independent AEUB Staff Submission Group (Staff Submission Group). It has long been accepted that matters may be initiated by the AEUB and particularly by the AEUB instructing the preparation of information or a submission by its staff. Such a process is legislatively authorized by the Energy Resources Conservation $A c t$, which provides that:

17 The [AEUB] may ...

(c) appoint from time to time persons having special technical or other knowledge of any matter before the [AEUB] to inquire into and report to the [AEUB] in respect of the matter in question, any of which persons may or may not be employees of the [AEUB], and

(d) appoint examiners, from its staff or otherwise, for the purpose of conducting hearings, inquirics and other investigations and reporting on them to the [AEUB]. ${ }^{123}$

The Staff Submission Group made in the 2003-023 proceeding was not initiated under this provision, nor was it ever made clear under what provision the Staff Submission Group was constituted. The AEUB's Rules of Practice, established just after the AEUB's Staff Submission Group submission was filed in connection with the 2003-023 proceeding, authorize such a submission to be made if, in the opinion of the AEUB, it is necessary or appropriate. ${ }^{124}$ In the 2003-023 proceeding, it became clear that the AEUB Staff Submission Group itself had decided to intervene to present a Staff Submission Group perspective. ${ }^{125}$ The absence of a clear direction from the AEUB concerning the purpose or necessity of the Staff Submission Group participation tended to raise some scepticism as to the objective behind the submission.

To the extent that the AEUB may decide to initiate a further review of grandfathered or previously-approved production, it is possible that more will be seen of the Staff Submission Group as a vehicle for the presentation of the evidence required for the AEUB to initiate such a review.

\section{iii. AEUB Staff Participation}

The role of the AEUB staff (as distinct from the Staff Submission Group) was raised as an issue in the context of the 2003-023 proceeding. In one instance, non-participating members of the AEUB staff developed and presented a technical paper at a conference conducted outside but during the same time frame as the 2003-023 hearing was being held. The paper presented conclusions that reflected an assessment of some of the evidence before the AEUB for consideration in the context of the 2003-023 hearing. The presentation of this paper raises an issue that implies a predetermination of the 2003-023 decision and it is on this very issue that leave to appeal has been sought. ${ }^{126}$ 
In a second instance, the AEUB advised near the end of the 2003-023 hearing that it intended to have members of its staff review certain core data and presumably report their assessment of that data to the AEUB after the conclusion of the hearing. An issue was raised with the AEUB as to what extent, if any, the AEUB should be entitled to rely on the assistance, advice and evidence provided by its staff for the preparation of its decision outside of the hearing room or after the hearing has been formally closed. Notably, a critical element to the AEUB's decision is a map entitled "Figure 8- Board's Interpretation of Areas of Erosion of McMurray A and B Mudstones in Chard-Leismer area." ${ }^{127}$ The decision does not indicate on what evidence it was made or who actually made that interpretation after the hearing concluded. These omissions may exemplify the procedural concern raised and which forms the subject of an application for leave to appeal to the Alberta Court of Appeal. ${ }^{128}$

\section{iv. Reasons for Decision}

At the time this article was prepared, several other procedural grounds had been raised on which leave to appeal the 2003-023 decision had also been requested. Notable among the issues raised are the adequacy of the AEUB's reasons for the decision which, it is contended, do not reflect either the basis for, or the evidence relied upon, in the AEUB's interpretations that are fundamental to its decision.

\section{Current Status ANd Future of the Gas/Bitumen Dispute}

\section{A. Status}

The AEUB's current approach to the gas/bitumen issue continues to operate on the premises and concerns advanced to it in the Inquiry Report and its response that it has a responsibility to ensure long-term bitumen recovery is not jeopardized by the production of gas that is in pressure communication with significant bitumen resources. Given the magnitude of the bitumen resources and of their future importance to Alberta, the AEUB continues to work from the position that future bitumen recovery should not be placed at risk.

From the time of the Inquiry Report, there has existed uncertainty concerning where the risk line should be drawn, how much risk the AEUB might be prepared to tolerate, and the reasonable measure of that risk. Zero risk could readily have been achieved by the AEUB by imposing a blanket restriction on gas production. After nearly five years of considering the issue, this is still not an approach the AEUB seems prepared to adopt. The initial policy determination by the AEUB that grandfathered production should not be disturbed without substantive reason provided additional indication that some level of risk was considered acceptable by the AEUB. It was the uncertainty as to the level of risk that gave rise to much of the evidence in the 2000-22 and 2003-023 proceedings. In each of these proceedings, attempts were made by both gas and bitumen interests to characterize and define what parties felt should be construed as the appropriate measure and level of risk.

13* Devon Canada Corporation's Application for Leave to Appeal, Appeal No. 0201-0174 AC. 
The 2003-023 decision now provides somewhat more clarity, albeit indirectly, as to what the AEUB is prepared to consider acceptable risk with regard to bitumen recovery. Given this clarification, it appears, in retrospect, that much of the evidence and the debate that occurred in all of the prior hearings, including the 2003-023 proceeding, has been considered by the AEUB to be largely superfluous. The AEUB's assessment of several factors can be described as cursory at best:

- the nature and significance of the issue and the conclusions to be derived from SAGD modelling;

- techniques to mitigate risk, including the potential for low pressure SAGD operations, artificial lift and repressuring; and

- economics and the possibility that significant amounts of bitumen resource, for which protection was considered, might never be produced using SAGD technology or at all.

In the 2003-023 decision, those issues prompted a great deal of evidence; the decision itself virtually ignored those issues, however. Instead the AEUB repeated the positions it had stated in earlier proceedings:

- There is very limited applicable field experience regarding the effect of associated gas production on SAGD bitumen recovery and the AEUB must rely on reservoir modelling to evaluate the issue. The AEUB's assessment is that producing gas that is associated with bitumen may present an unacceptable risk to SAGD bitumen recovery. ${ }^{129}$

- Remedial measures, such as repressurization of a depleted Wabiskaw-McMurray gas zone, may be shown to be a viable option in the future. However, the AEUB continues to believe that repressuring should not be relied upon until it has been proven to be feasible and practical on the basis of field tests. ${ }^{130}$

- The AEUB is concerned that risks associated with SAGD bitumen production increase at lower operating pressures, from which it concluded that gas zone depressuring should be kept to a minimum. ${ }^{\mid 31}$

- The AEUB is not prepared, given the numerous unknowns respecting the fact that SAGD technology is in its infancy, to abandon bitumen for perceived economic reasons and, to that end, has embraced the view that the value to society of the bitumen resources that are amenable to SAGD, compared to the value of gas reserves. is essentially a comparison of billions to millions. ${ }^{132}$

In like fashion, the AEUB "shuffled off of the table" other apparently non-determinative considerations, including:

- rejecting an argument that regions of hydraulic continuity can be used to define minimum regions of influence; ${ }^{133}$

Supra nole 4 al 33

Ibid. al 34.

Ibid. at 35.

Ibid. at 36.

Ibid. at 13. 
- determining that pressure behaviour observations do not allow conclusions to be drawn regarding regional aquifer continuity or lateral pressure transmission; ${ }^{134}$

- rejecting gas pool and aquifer simulation models as not being precise in terms of time, distance and rate of pressure transmission; ${ }^{135}$ and

- confirming that it is not possible to establish definitively the actual size and shape of regions of influence. ${ }^{136}$

These are all factors noted by the AEUB not to be sufficiently definitive for purposes of its decision-making. The AEUB's approach to these factors leads to two observations with respect to acceptable risk. First, the effective test that the AEUB appears to have established is that an acceptable level of risk is achieved only when the AEUB's concerns are alleviated. Second, to alleviate the AEUB's concerns, a level of certainty that approaches definitiveness must be established. It might be noted that these are not only difficult, but highly subjective criteria. None of this bodes well for the adoption of any of these other assessment criteria. Rather, the AEUB has focused exclusively on geological interpretation. At some point, the AEUB may decide that it is more prepared to adopt an approach that reflects a balancing of the best available evidence. For the present, however, that is not the approach that has been selected. Looking forward, it seems unlikely that the definitive evidence the AEUB seeks to alleviate its concerns will exist, at least not in the near future. Actual SAGD operating and production experience, repressuring experience and economic factors may eventually become more relevant. For this to occur, it will be necessary for the AEUB to identify in a positive fashion what it might consider acceptable in order to provide a useful measure of those factors.

So far, the AEUB has identified substantive measures only in terms of the observed bitumen thickness and bitumen pore volume saturation and in terms of whether the bitumen is physically likely to be in pressure communication with the gas pools that are proximate to bitumen resources. With respect to the latter issue, as noted above, the 2003-023 decision has added substance to the geologic basis upon which the AEUB may be prepared to conclude that there exists adequate evidence of pressure separation between gas and bitumen.

It is difficult to conclude objectively that the geologic evidence relied upon by the AEUB as substantive is any more definitive than is any of the evidence rejected by the AEUB as not being sufficiently definitive. Notwithstanding this observation, the AEUB has landed on geologic interpretation as its touchstone to answer the one question it considers to be significant: whether the gas under consideration is "associated" with bitumen. To answer this question, the AEUB arrived at geologic conclusions with respect to both vertical and lateral segregation. Specifically, with respect to the potential for vertical communication, the AEUB concluded that

- where the McMurray B regional mudstone is absent, potential for vertical communication for all sediments below the McMurray A regional mudstone is likely; 
- where the McMurray A regional mudstone is absent, but the McMurray $B$ regional mudstone is present, the AEUB found that the sand above the McMurray B regional mudstone remains vertically isolated from underlying sediments;

- where the McMurray A and B regional mudstones are absent, all sediments below the Wabiskaw $D$ shale have the potential to be in vertical communication;

- where the Wabiskaw D shale is absent or less than 0.5 metres thick, isolation of the overlying Wabiskaw $\mathrm{C}$ sand from the underlying McMurray channel bitumen is dependent on the presence of either the McMurray A or B regional mudstones; and

- where the Wabiskaw $C$ channel has removed the regional Wabiskaw $D$ shale and McMurray A and B mudstones, the AEUB found that there is potential for vertical communication between the Wabiskaw $C$ channel gas and underlying McMurray channel bitumen. ${ }^{137}$

With respect to the potential for lateral communication, the AEUB concluded that:

- lateral communication pathways do not commonly exist between regional Wabiskaw C, McMurray A, McMurray B2 and Wabiskaw D valley-fill gas pools and/or top water zones and McMurray channel gas pools and/or top water zones;

- the potential for lateral communication between McMurray Bl gas pools and McMurray channel gas pools is limited; and

- the potential exists for McMurray channel gas pools to be associated with underlying channel bitumen. ${ }^{138}$

These vertical and lateral communication criteria appear to represent the currentlyestablished parameters to determine which gas accumulations that may be in association with bitumen might warrant consideration for protection. These criteria, as noted by the AEUB, were the basis for the 2003-023 decision, which indicates that

the [AEUB] has assessed the Wabiskaw-McMurray gas zones in the wells included in the applications considered at the hearing with respect to whether or not these gas zones have a high or low potential to be in pressure communication with underlying channel bitumen. This assessment is based on the [AEUB's] conclusions regarding the Wabiskaw-MeMurray stratigraphy and the potential for vertical and/or lateral communicalion. ${ }^{139}$

\section{B. FUTURE}

The gas/bitumen debate is likely to continue for a significant period into the future, although its potential and scope should be considerably narrowed. Geological interpretation, particularly of areas where channelling may be construed, would seem to represent the extent of the questions to be determined relative to whether gas may be produced. On that basis the AEUB appears intent on expediting the shut-in of substantially more gas production in the Athabasca Oil Sands Deposit. Given the magnitude of the issue and the resource base that the AEUB has identified as being potentially at risk, it seems clear that the AEUB will 
continue to reflect the view that the bitumen resources that are associated with gas, particularly those within the Athabasca Oil Sands Deposit trend area, will warrant protection until such time as a resolution to the issue is otherwise established.

If this establishes the scope of the shut-in of gas production, then the focus may turn more to the question of when and on what terms precluded or shut-in gas production may be reactivated. This gives rise to considerations of where the greater opportunity may exist for a solution that will facilitate the concurrent production of gas and bitumen. It may be, for example, that a resolution may come from better and more factual information, or better data gathering, or from actual SAGD experience. A resolution may also hinge on future advances in technology or may be driven by changes in policy or in law.

\section{MORE AND BETTER EVIDENCE}

The one significant established fact that is and will be the driving force behind the gas/bitumen issue is the magnitude of the bitumen resource.

Notwithstanding the voluminous nature of the evidence that has been put before the AEUB in prior proceedings, there is relatively little hard evidence of a factual nature that has been established clearly or even is accepted generally. As no touchstone exists to confirm the problem, there is little focal point for a future solution. As the problem is of a potential nature, it is unlikely that more and better information will have a very significant impact on the perspective of uncertainty held by the AEUB, at least until the problem's existence is confirmed. It will be difficult and likely impossible, using the AEUB's approach, to demonstrate the absence of any problem. Information that may be derived from additional drilling or from pressure-monitoring is unlikely to add either significantly or sufficiently to the database to dispel the AEUB's current concerns. In the 2003-023 proceeding, the AEUB was encouraged to mandate the acquisition of more detailed information though a requirement for a higher drilling density as a pre-condition to obtaining approval to produce gas. Although the AEUB rejected the specific concept because it was impractical, it did not even endorse the concept that information from a higher drilling density would provide materially better factual information.

As well bores provide direct information about an area only a few inches in diameter, it will always be necessary to infer conclusions about the much broader areas that exist between data points. The acquisition of more and better evidence is likely always to be considered desirable, particularly with respect to local geological interpretation. However, the acquisition of more core and log data alone is unlikely to provide the basis for any broadbased solution to the gas/bitumen issue.

Pressure data, although informative, is also unlikely to be construed by the AEUB as sufficiently definitive that it can be relied upon to provide a broad-based resolution to the gas/bitumen issue. The AEUB is of the view that currently available pressure data is of insufficient quality and quantity to provide definitive answers. In the 2003-023 decision, the AEUB observed that the quality of the pressure data in the area was poor because of "infrequent pressure testing, the amount of commingled gas production in the area, and the 
practice of measuring pressure at the surface."1+0 The AEUB raised similar concerns about the veracity of pressure data derived from observation well piezometers. Some potential exists for better pressure data to be obtained and, to that end, the AEUB encouraged gas and bitumen owners to work together to develop pressure monitoring programs acceptable to all parties. ${ }^{141}$

It is the hope of many interested parties that field experience, as well as more and better data, will be of benefit in adding to the understanding of SAGD. The AEUB has determined what is unacceptable evidence and field analogs. The lack of any definition as to the representative evidence necessary to satisfy the AEUB does not provide much in the way of comfort that such evidence will exist or can ever be provided.

\section{THE POTENTIAL, OF TECHNOLOGY}

Probably the greatest potential for a resolution to the gas/bitumen issue rests with future technological developments. It needs to be clearly understood, though, that "the [AEUB] believes that it would not be in the public interest to risk significant volumes of bitumen resources on the presumption that alternative technology will be developed."142

All parties (bitumen producers, gas producers and government) appear to recognize the need for creative collaboration outside of the hearing process to seek out and find technological solutions. To this end, oil and gas companies working with Alberta government departments have established a collaborative Gas Over Bitumen Steering Committee (Steering Committee) to develop technological solutions to the gas/bitumen issue. The Steering Committee's challenge is to find ways to allow for the production of gas without causing significant risk to future bitumen recovery. To that end, five technical subcommittees are focusing on potential solution areas, including:

- lateral and vertical pressure and fluid communication;

- artificial lift technology;

- SAGD performance at low pressures;

- data-gathering and interpretation on shut-in wells; and

- advanced technology associated with fluid injection into gas pools overlying bitumen.

Key activities currently underway by the Steering Committee and its subcommittees include:

- pressure data - clean up of existing Surmont shut-in pressure data and development of a consistent pressure data-gathering program;

- Low Pressure SAGD - further study of Low Pressure SAGD including the potential for a field pilot project; and

- artificial lift - further study towards the development of improved artificial lift technology to be used in Low Pressure SAGD. 
It will be imperative that all interested parties, namely, bitumen developers, gas producers, the AEUB and the Alberta government continue to work together to find answers to the questions being debated and solutions to any real resource conservation issues that exist. Considering the gas reserves that have been or will be shut-in and the chill that the gas/bitumen issue has placed over further gas development, the prize associated with finding these answers and solutions should be significant.

Additional SAGD experience should, in the future, assist in better establishing under what, if any, parameters gas may be allowed to produce. It is unlikely, though, that the results of any single SAGD project, such as the Surmont pilot project, alone will produce sufficiently representative information to cause a reversal in the cautious approach currently employed by the AEUB. Given the significant variability in the geology in the Wabiskaw-McMurray region, the Surmont data, even when available, will probably be considered an unrepresentative analog to other areas, just as the Dover SAGD data was considered unrepresentative of Surmont. ${ }^{143}$

As a result, the existing rationale for the shut-in of gas is likely to remain in place at least until reliable conclusions evolve from a number of disparate projects. Given the 20 to 25 -year life of a SAGD project, this should put any potential resolution, based on actual SAGD data, significantly further into the future.

There is similarly little reason for optimism that repressuring will provide any greater potential for an early resolution to the gas/bitumen issue. This not because of any technological reason, but rather because the AEUB has consistently cautioned that even if "in some situations repressuring of a depleted Wabiskaw-McMurray gas zone may be shown to be a viable option in the future, it continues to believe that repressuring should not be relied on until it has been proven to be feasible and practical on the basis of field tests." 144

The AEUB has also made it clear that more than one repressuring project will have to be shown as ultimately successful to assess and ensure that "the results are applicable to other areas and geological conditions."145

Industry optimism appears to be generally high that artificial lift technology will evolve as required. This may be because the technology is currently being developed or because it is essential many existing gas pool pressures are already depleted below the gas lift pressure range. Hence, other artificial lift technology will likely be essential to SAGD bitumen production in low pressure areas in any event. ${ }^{146}$ The AEUB, though, has paid little heed to the artificial lift issue and has instead has suggested that "gas zone depressuring should be kept to a minimum to better ensure successful SAGD operations in terms of resource recovery and minimizing the technical difficulty of lifting SAGD fluids." ${ }^{147}$ As a result, it appears advances in artificial lift technology are unlikely to add very much to the opportunity for gas and bitumen to be produced concurrently.

2000-22, supra note 2 at 21 .

2003-023, supra note 4 at 34 .

Ibid.

2003-023, supra note 4 at 35 .

lbid. 
One technological area where a real opportunity for a resolution to the gas/bitumen issue might rest is with the evolution and development of low pressure SAGD technology. It will, though, take a commitment by bitumen operators actually to employ the technology in a commercial context before the AEUB is likely to be persuaded it provides an effective resolution to the gas/bitumen issue. Proving the success of low pressure SAGD technology will likely require several successfully completed projects, which means a resolution to the concurrent production of gas and bitumen issue should be more than twenty to thirty years into the future.

\section{NEW POL.ICY APPROACHES}

The direction indicated by the AEUB is towards the establishment of a policy position that identifies the trend area where bitumen with the highest potential for development may be at risk, with a view to curtailing much of the associated gas production within that area. What has not yet been established is the scope of this trend area.

Policy issues are evolving with respect to future processes. The AEUB has made it clear that it intends to develop and implement a process that will address grandfathered and other production that it considers could present a significant risk to future bitumen recovery. ${ }^{148}$ The intent of GB 2003-12, ${ }^{149}$ which invites further general submissions as to the identification of other gas to be shut-in, appears to foreshadow a new policy that will place the AEUB's emphasis entirely on its conservation concerns as identified by geologic interpretation.

Although the AEUB has expressed little optimism that there are voluntary alternative resolution mechanisms that would be acceptable to the parties, it has said it would encourage parties to evaluate the merits of the various alternative dispute resolution options. ${ }^{\text {so }}$ Beyond verbal encouragement, though, the AEUB's policy approach has been to make the gas/bitumen issue a regulatory issue, exclusively determined by the AEUB's interpretations. This approach by the AEUB provides little incentive or meaningful opportunity for parties to seek other resolutions.

It appears doubtful that new or other policy approaches will be introduced by the AEUB or the government to facilitate the concurrent production of gas and bitumen or that the current policy approach of protecting potentially at-risk bitumen will change.

The area where new policy development is likely to play the most significant role will be with respect to compensation, if any, for shut-in gas. There are three potential approaches that may be employed by the government: negotiate compensation in the manner done with respect to shut-in gas at Surmont; ask the AEUB to prepare a compensation scheme pursuant to s. 99 of the Oil and Gas Conservation Acr; ${ }^{131}$ or refuse compensation entirely - an approach likely to incite litigation. 


\section{LEGAL RESOLUTIONS}

Although some of the legal challenges have provided and are likely to continue to provide interesting legal debate, those challenges in the bigger picture are likely to do little more than assist in establishing rules for a better or more reasonable process. A legally-directed resolution to the gas/bitumen issue is, overall, unlikely.

Arguably, a resolution based on new law might have been a more effective and efficient approach from the outset than has been the regulatory approach established by the AEUB. The AEUB has substantial authority under the Energy Resources Conservation Act, ${ }^{152}$ pursuant to which it has the opportunity to recommend a legislative resolution. However, so far, it has elected not to seek any direct or obvious support from the government in terms of establishing either an approach or direction for specific or more comprehensive solutions.

Overall, it should be expected that in the near future, at least, the AEUB's decisions will continue to be primarily based on the view that bitumen resources in the area are large, representing Alberta's energy future and, on that basis, that they warrant significant protection. In the absence not only of reliable but of definitive information that producing gas will not create a risk to future bitumen recovery, the AEUB will continue to ensure that gas production does not materially compromise future potential bitumen recovery.

The gas/bitumen issue is big and growing. It is complex with no easy solutions. It also carries the possibility of a great prize, namely, the ability to develop both gas and bitumen resources, each at its own pace without obstruction or risk from the other. Interested parties (bitumen developers, gas producers, the government and the AEUB) need to be encouraged to work together to seek the solutions necessary. It is possible, if remotely so, that these solutions may already be within reach. Even if not, given the size of the prize, the search is likely to be worth the price.

The Board may, and at the request of the Lieutenant Governor in Council shall, at the places, at the limes and in a manner it considers advisable

(a) make inquiries and investigations and prepare studies and reports on any malter within the purview of any Act administered by it relating to energy resources and energy, and

(b) recommend to the Lieutenant Governor in Council any measures it considers necessary or advisable in the public interest related to the exploration for, production, development, conservation, control, transportation, transmission, use and marketing of energy resources and energy. 


\section{APPENDIX 1 \\ ATHabasca Oll Sands AREA - MAP 4 (Revised November 2000) ATTACHMENT 4 TO ID 99-1 AMENDMENT ${ }^{\text {153 }}$}

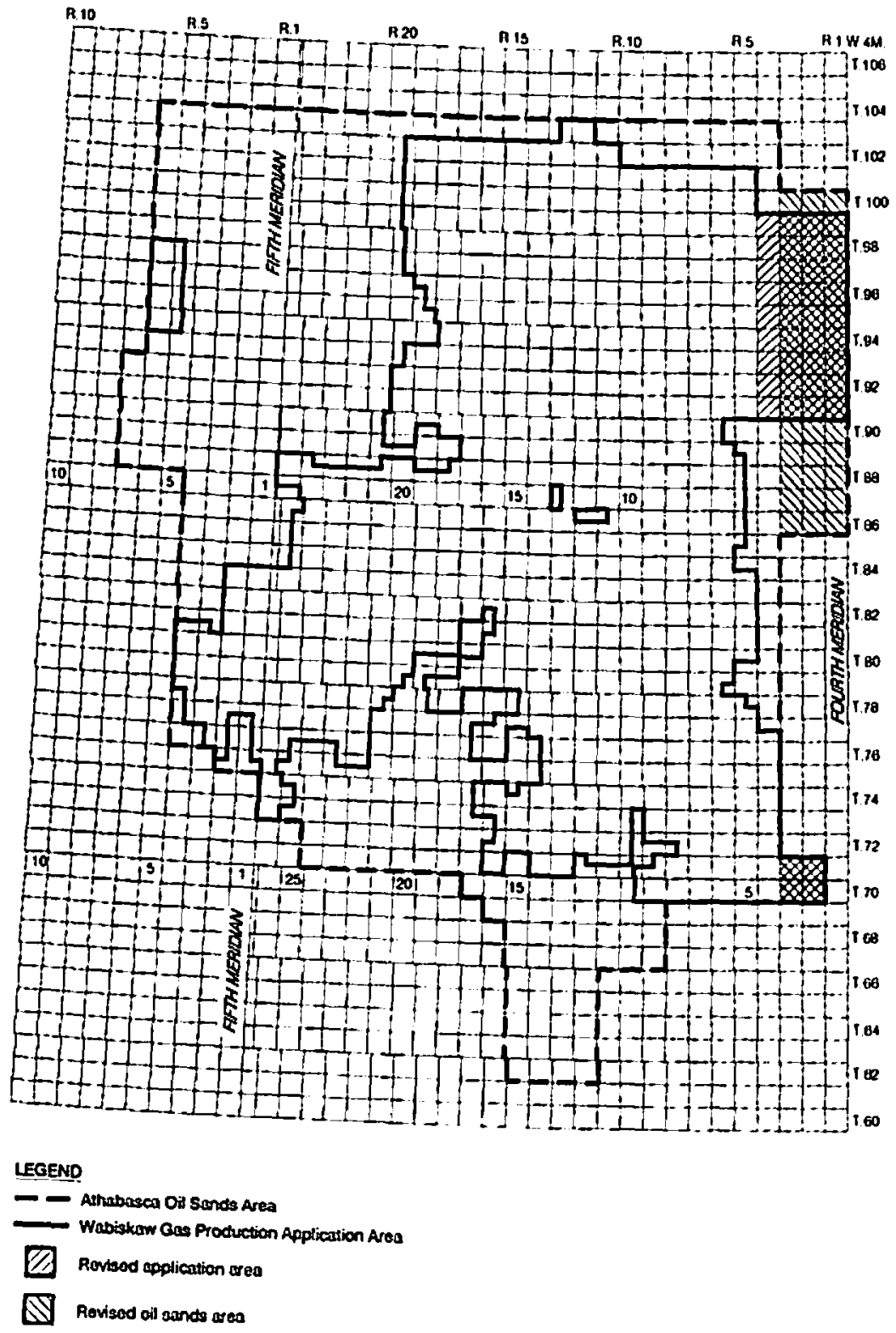


APPENDIX 2

SCIIEMATIC Cross-Section OF THE

Steam Assisted Gravity Drainage (SAGD) Process ${ }^{154}$

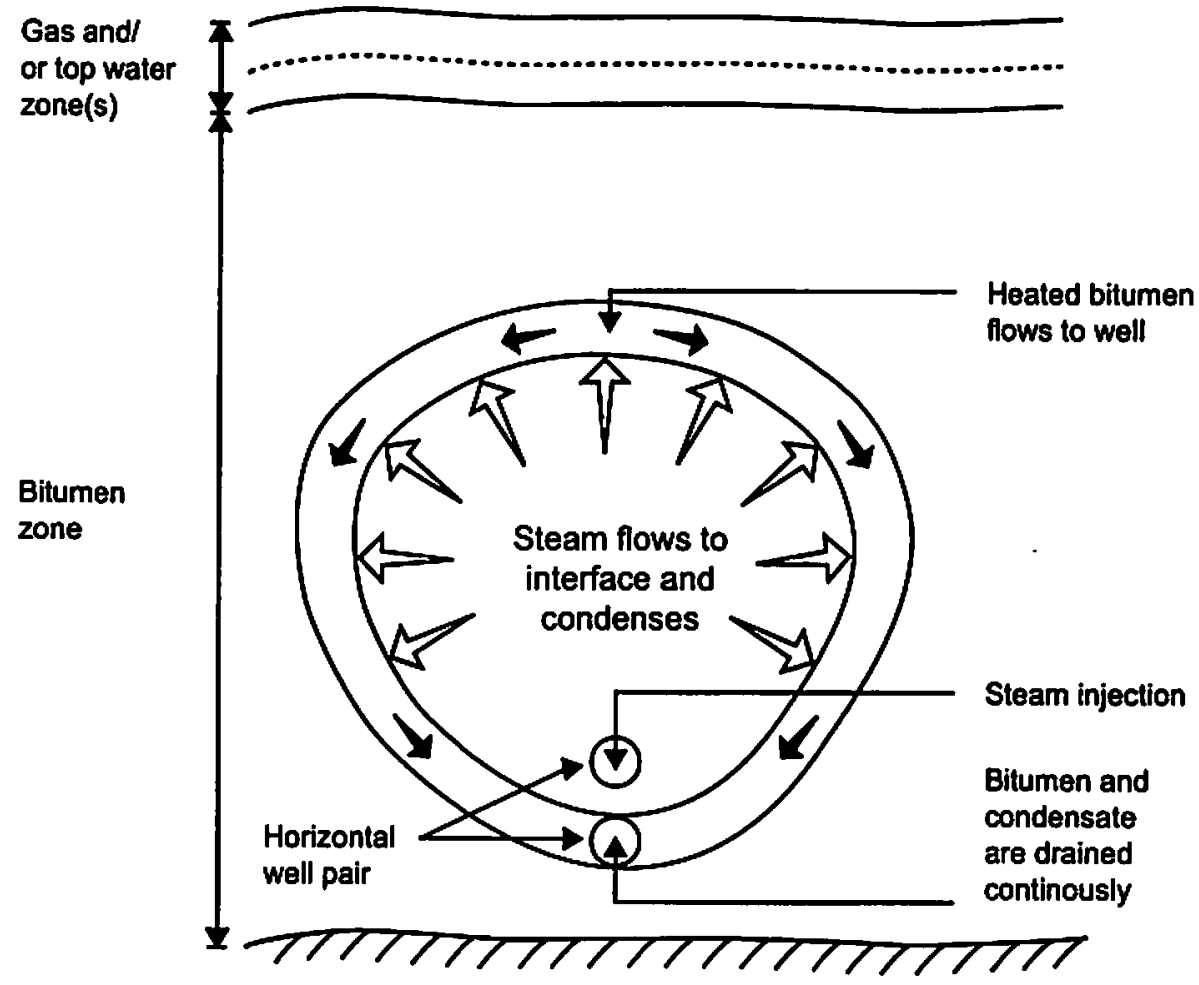

134. Supra note 20. 